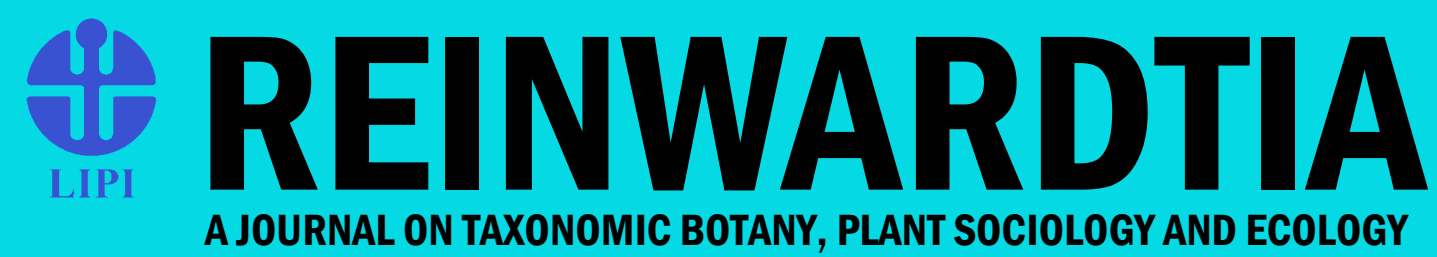

ISSN 0034 - 365 X | E-ISSN 2337 - 8824 | Accredited 792/AU3/P2MI-LIPI/04/2016
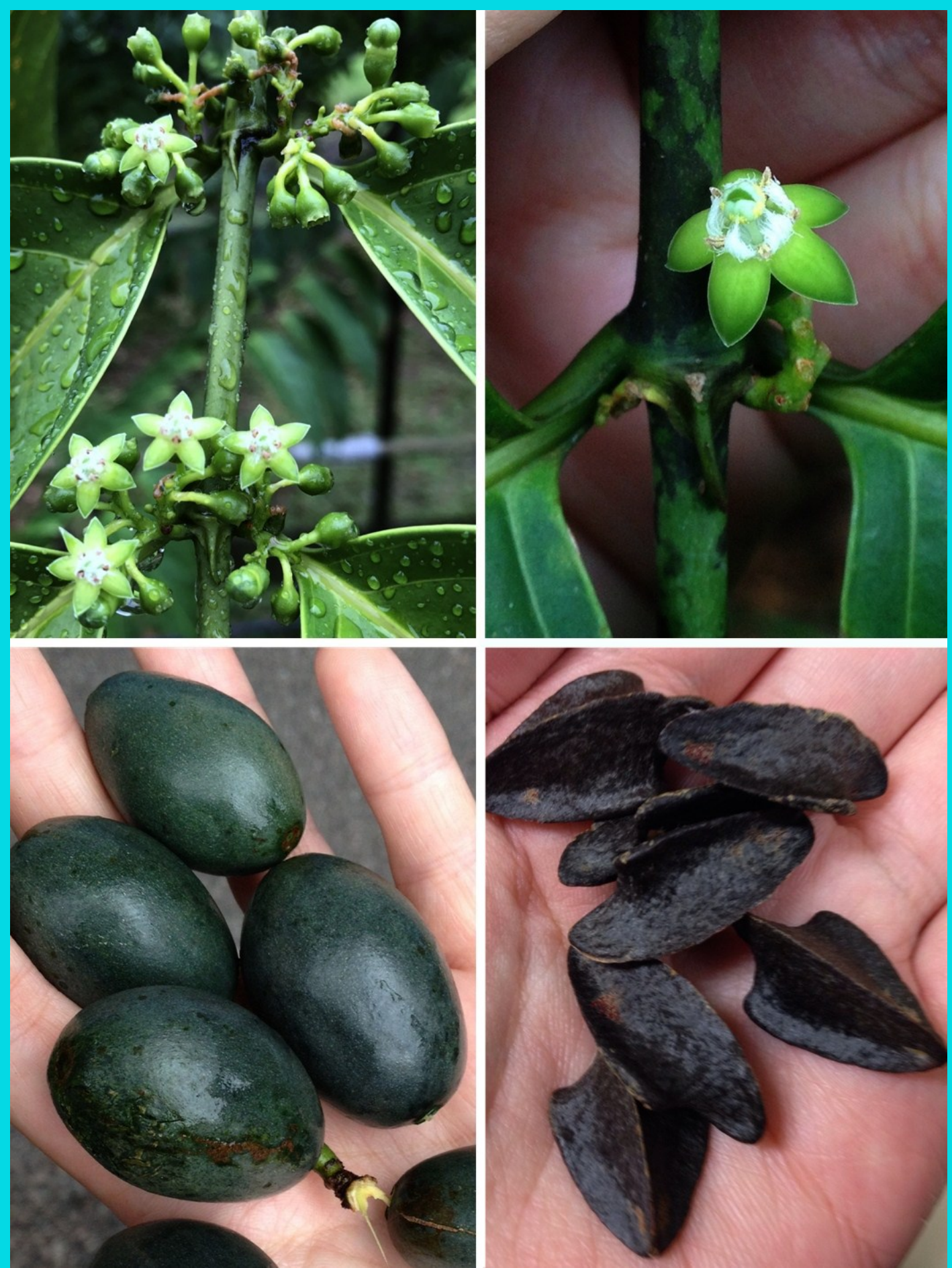

$201817(2)$ 


\section{REINWARDTIA}

\section{A JOURNAL ON TAXONOMIC BOTANY, PLANT SOCIOLOGY AND ECOLOGY}

Vol. 17 (2): 87 - 154, December 18, 2018

\section{Chief Editor}

Kartini Kramadibrata (Mycologist, Herbarium Bogoriense, Indonesia)

\section{Editors}

Dedy Darnaedi (Taxonomist, Herbarium Bogoriense, Indonesia)

Tukirin Partomihardjo (Ecologist, Herbarium Bogoriense, Indonesia)

Joeni Setijo Rahajoe (Ecologist, Herbarium Bogoriense, Indonesia)

Marlina Ardiyani (Taxonomist, Herbarium Bogoriense, Indonesia)

Himmah Rustiami (Taxonomist, Herbarium Bogoriense, Indonesia)

Lulut Dwi Sulistyaningsih (Taxonomist, Herbarium Bogoriense, Indonesia)

Topik Hidayat (Taxonomist, Indonesia University of Education, Indonesia)

Eizi Suzuki (Ecologist, Kagoshima University, Japan)

Jun Wen (Taxonomist, Smithsonian Natural History Museum, USA)

Barry J. Conn (Taxonomist, School of Life and Environmental Sciences, The University of Sydney, Australia)

David G. Frodin (Taxonomist, Royal Botanic Gardens, Kew, United Kingdom)

Graham Eagleton (Wagstaffe, NSW, Australia)

\section{Secretary}

Ruslan Bukhori

\section{Layout}

Liana Astuti

\section{Illustrators}

Subari

Wahyudi Santoso

Anne Kusumawaty

Correspondence on editorial matters and subscriptions for Reinwardtia should be addressed to:

HERBARIUM BOGORIENSE, BOTANY DIVISION,

RESEARCH CENTER FOR BIOLOGY - INDONESIAN INSTITUTE OF SCIENCES

CIBINONG SCIENCE CENTER, JLN. RAYA JAKARTA - BOGOR KM 46,

CIBINONG 16911, P.O. Box 25 CIBINONG

INDONESIA

PHONE (+62) 21 8765066; Fax (+62) 218765062

E-MAIL: reinwardtia@mail.lipi.go.id

http://e-journal.biologi.lipi.go.id/index.php/reinwardtia

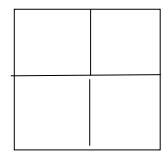

Cover images: Canthiumera robusta K.M.Wong \& X.Y.Ng, spec. nov. Top left: leafy branch with inflorescences; note also keeled stipules. Top right: flower with tufts of pale moniliform hairs visible opposite corolla lobes. Below left: fruits. Below right: pyrenes. Photos: Ang Wee Foong (top left) and X.Y. Ng (remaining images). 
The Editors would like to thank all reviewers of volume 17(2):

Andrew Powling, School of Biological Sciences, University of Portsmouth, Portsmouth, United Kingdom George Argent, Royal Botanic Garden Edinburgh, Edinburgh, United Kingdom

Joan Pereira, Forest Research Centre, Sandakan, Sabah, Malaysia

Jun Yokoyama, Dept. of Biology, Faculty of Science, Yamagata University, Yamagata, Japan

Khoon Meng Wong, Singapore Botanic Gardens, Singapore

Kongkanda Chayamarit, Queen Sirikit Botanic Garden, P.O. Box 7, Mae Rim, Chiang Mai, Thailand 


\title{
TREE SPECIES DIVERSITY IN A PRISTINE MONTANE FOREST PREVIOUSLY UNTOUCHED BY HUMAN ACTIVITIES IN FOJA MOUNTAINS, PAPUA, INDONESIA
}

\author{
Received 06 August, 2018; accepted 04 October, 2018
}

\author{
ASEP SADILI \\ Herbarium Bogoriense, Research Center for Biology, Indonesian Institute of Sciences (LIPI), Jln. Raya Jakarta-Bogor \\ Km 46, Cibinong 16911, Indonesia.Email: asep.sadili@gmail.com
}

\author{
KUSWATA KARTAWINATA \\ Integrative Research Center, The Field Museum, 1400 Lake Shore Drive, Chicago, IL 60605, USA, Email: \\ kkjak@indo.net.id
}

\section{HERWASONO SOEDJITO}

Herbarium Bogoriense, Research Center for Biology, Indonesian Institute of Sciences (LIPI), Jln. Raya Jakarta-Bogor Km 46, Cibinong 16911, Indonesia.Email: herwasonosoedjito@yahoo.com

\section{EDY NASRIADI SAMBAS}

Herbarium Bogoriense, Research Center for Biology, Indonesian Institute of Sciences (LIPI), Jln. Raya Jakarta-Bogor Km 46, Cibinong 16911, Indonesia.Email: edynas.sambas@gmail.com

\begin{abstract}
SADILI, A., KARTAWINATA, K., SOEDJITO, H. \& SAMBAS, E. N. 2018. Tree species diversity in a pristine montane forest previously untouched by human activities in Foja Mountains, Papua, Indonesia. Reinwardtia 17(2): 133-154. - A study on structure and composition of the pristine montane forest previously untouched by human activities was conducted at the Foja Mountains in November 2008. We established a one-hectare plot divided into 100 subplots of $10 \mathrm{~m} \times 10 \mathrm{~m}$ each. We enumerated all trees with DBH $\geq 10 \mathrm{~cm}$ which diameters were measured, heights were estimated and habitats were noted. We recorded 59 species, 42 genera and 27 families, comprising 693 trees with the total basal area (BA) of $41.35 \mathrm{~m}^{2} / \mathrm{ha}$. The forest had lower species richness compared to those of lowland forests in Kalimantan, and Sumatra and montane forests in West Java. The Shannon-Wiener's diversity index was 3.22. Nothofagus rubra (Importance Value, $I V=47.89 \%)$ and Parinari corymbosa $(\mathrm{IV}=40.3 \%$ ) were the dominant species, constituting the basis for designating the forest as the Nothofagus rubra-Parinari corymbosa association. To date, the dominance of N. rubra is unique to the Foja Mountains, as elsewhere in Papua the montane forests were dominated by $N$. pullei or other species. The species-area curve indicated a minimal area of $5000 \mathrm{~m}^{2}$. On the family level Fagaceae (IV=53.23\%), Chrysobalanaceae (IV=40.53\%) and Myristicaceae (IV=26.43\%) were dominant. Vertically the forest consisted of four strata (A-D). In each stratum Nothofagus rubra, Platea latifolia, Parinari corymbosa and Myristica hollrungii were dominant. The diameter class distribution of Nothofagus rubra, Parinari corymbosa and Platea latifolia led us to assume that these species were regenerating well.
\end{abstract}

Key words: Association, composition, Foja, montane forest, Papua, structure.

\begin{abstract}
ABSTRAK
SADILI, A. KARTAWINATA, K. SOEDJITO, H. \& SAMBAS, E. N. 2018. Keanekaragaman jenis pohon di dalam hutan pegunungan yang belum terjamah kegiatan manusia di Pegunungan Foja, Papua, Indonesia. Reinwardtia 17(2): 133-154. - Kajian struktur dan komposisi hutan pegunungan alami yang belum terjamah manusia di hutan Pegunungan Foja dilakukan pada bulan November 2008. Kajian menggunakan petak satu hektar, yang dibagi menjadi 100 anak petak masing-masing berukuran $10 \mathrm{~m} \times 10 \mathrm{~m}$. Semua pohon berdiameter $\geq 10 \mathrm{~cm}$ diukur diameternya, ditaksir tinggi totalnya, dan dicatat habitatnya. Dari pendataan 693 individu tercatat 59 jenis, 42 marga, dan 27 suku, dengan luas bidang dasar 41,35 $\mathrm{m}^{2} /$ ha. Kekayaan jenis lebih rendah dari hutan pamah Kalimantan, Sumatera, dan hutan pegunungan di Jawa Barat. Indeks keragaman Shannon-Wiener= 3.22. Nothofagus rubra dengan Nilai Kepentingan $\mathrm{NK}=47.89 \%$ dan Parinari corymbosa dengan $\mathrm{NK}=40.53 \%$ adalah jenis dominan dan menjadi landasan untuk menyebut tegakan hutan dalam plot sebagai asosiasi Nothofagus rubra-Parinari corymbosa. Jenis $N$. rubra merupakan jenis dominan yang unik bagi hutan Pegunungan Foja, sedangkan hutan pegunungan lain di Papua didominasi oleh $N$. pullei atau jenis lain. Kurva jenis-area menunjukkan luas $5.000 \mathrm{~m}^{2}$ sebagai luas minimal. Fagaceae $(\mathrm{NK}=53.23 \%)$, Chrysobalanaceae $(\mathrm{NK}=40.53 \%)$ dan Myristicaceae $(\mathrm{NK}=26.43 \%)$ adalah suku dominan. Secara vertikal hutan terdiri dari empat lapisan (A-D). Setiap lapisan didominasi Nothofagus rubra, Platea latifolia, Parinari corymbosa, dan Myristica hollrungii. Berdasarkan distribusi kelas diameter bagi Nothofagus rubra, Parinari corymbosa dan Platea latifolia adalah jenis yang regenerasinya sangat baik.
\end{abstract}

Kata kunci: Asosiasi, Foja, hutan pegunungan, komposisi, Papua, struktur. 


\section{INTRODUCTION}

New Guinea is the largest tropical island, covering a total area of $\pm 900,000 \mathrm{~km}^{2}$ (Polak, 2000). Politically it encompasses Indonesian New Guinea (consisting of the Papua and West Papua Provinces) to the west and Papua New Guinea to the east. Phytogeographically New Guinea belongs to the floristic region of Malesia (Steenis, 1950; Balgooy, 1976). The vegetation and climate of Papua are diverse (Hope, 1976; Paijmans, 1976; Kartikasari et al., 2012). The high plant species diversity of Papua (Johns, 1993; Johns et al., 2007; Kartawinata, 2013) contributes to the status of Indonesia as one of the megadiversity countries, besides Brazil and Zaire (BAPPENAS, 2003; LIPI et al., 2013). It is the home and habitat of 124 endemic plant genera (Kartawinata, 2013; Steenis, 1950). The conservation areas in Papua cover $7,755,284$ ha (KLHK, 2016). The Foja Mountains and the surrounding lowland forest were declared as the Foja Wildlife Refuge (Suaka Margasatwa Foja) by the Minister of Forestry SK No. 3028/ Menhut-VII/KUH/2014 on 17 April 2014 and SK No. 3076/Menhut-VII/KUH/2014 on 23 April 2013. Along with other forest areas they were later proposed as a national park (Roberth, 2016).

Vegetation studies in Papua have been relatively fewer compared to those in Papua New Guinea. The existing results of vegetation studies in the lowland and highland of Papua have been synthesized by Johns et al. (2007) and Bowe et al. (2007). Past studies were primarily qualitative reports complementing botanical explorations, including those by Archbold et al. (1942), Brass (1941), Gibbs (1917), Kalkman (1963), and Lam (1945).

In Papua, Gibbs (1917) was the first botanist who classified the vegetation and recorded the flora of the Arfak Mountains. He noted the lower montane forest was dominated by Araucaria and Lithocarpus, and low mossy montane forest above $2,100 \mathrm{~m}$ asl was dominated by short trees of Phyllocladus, Papua cedrus, and Dacrycarpus. Later Lane-Poole (1925) tried to classify the vegetation of the entire New Guinea, including Papua. He identified lower montane forest zone (300-1,700 m asl), mid montane forest $(1,700$ $2,250 \mathrm{~m}$ asl), mossy forest $(2,250-3,350 \mathrm{~m}$ asl) and high montane forest ( $>3,350 \mathrm{~m}$ asl). This classification is comparable to that of Johns et al. (2007).

The third Archbold expedition was undertaken in the Snow Mountains, with Mt. Jaya as the summit at the altitude of 4,886 $\mathrm{m}$ asl (Archbold et al., 1942; Brass, 1941). Brass (1941) proposed a tentative classification of the main vegetation of New Guinea as follows: savanna and savanna forest $(0-1,700 \mathrm{~m}$ asl); monsoon forest $(0-450 \mathrm{~m}$ asl), rain forest $(0-2,400 \mathrm{~m}$ asl), mid-mountain forest (480-2,350 m asl); beech forest (850-3,100 $\mathrm{m}$ asl); mossy forest (1,500-3,200 $\mathrm{m}$ asl); sub-alpine forest $(3,000-4,050 \mathrm{~m}$ asl); and alpine grassland (2,900 $\mathrm{m}$ asl-snowline), but he did not indicate the type of vegetation at the elevation of $2,400-3,000 \mathrm{~m}$. Partly based on the 1919-1920 expedition to the Doorman Top, a small mountain covered by ultramafic vegetation, Lam (1945) summarized the vegetation of New Guinea but did not propose any vegetation classification based on altitudes. Johns et al. (2007) listed earlier expeditions by Beccari to the Arfak Mountains, Wollaston and Kloss to Mt. Jaya, Colijn in 1936, Lorentz-van Nouhuys in 1909, Herderschee in 1913, and Kalkman in 1963 in the Star Mountain.

More recent vegetation studies in the Mt. Jaya area were conducted by Hope (1976) and on Mt. Trikora by Mangen (1993). Hope (1976) identified upper montane forest dominated by Nothofagus pullei; lower subalpine forest dominated by Dacrycarpus compactus and Trochocarpus nubicola; shrubland-grassland dominated by Coprosma brassii and Deschampsia klossii; tree-fern tussock grassland dominated by Cyathea pseudomuelleri and Deschampsia klossii; tussock grassland dominated by Deschampsia klossii; communities on open rocky slopes dominated by grasses, mosses and lichens, subalpine bog communities dominated by short grasses and short shrubs and alpine vegetation composed of grassland, dwarf heath scrub, moss and short scrub and tundras.

Most recent studies were conducted by Shea et al. (1998) in the forests within the Freeport concession area on the southern side of the Carstensz mountain around Tembagapura. They indicated Hopea papuana, Lithocarpus sp., Symplocos cocchinchinensis, Syzygium anomala, Elaeocarpus sepikensis, Anisoptera thurifera and Castanopsis acuminatissima as common tree species. They identified a Lithocarpus sp., Tristania sp., association, Symplocos cochinchinensis-Elaeocarpus sp. association, Anisoptera thurifera-Castanopsis acuminatissima association and Neolamarckia cadamba-Ficus sp. association.

Polak (2000) investigated the botanical diversity and its relation to soil and geological substrata in the karst-dominated Ayawasi area (Bird's Head Peninsula), and recorded Myrtaceae, Burseraceae, and Euphorbiaceae as the most frequent families and Myrtaceae, Lauraceae, and Meliaceae as the most species-rich families. Keim et al. (unpublished, 2018) reported a floristic and vegetation survey around the Habbema Lake. They identified lower montane forest, upper montane forest, mossy forest, subalpine forest, subalpine scrub, subalpine grassland and tropical alpine vegetation, comprising grassland, heath 
scrub and tundra. Nothofagus brassii and N. pullei characterized the upper montane forest and mossy forest. They included also a description of vegetation types beyond Lake Habbema up to Mt. Jaya, although these areas were not visited during the survey. They also recorded the occurrence of dieback in Nothofagaceae.

The Foja-Mamberamo forest (see Fig. 1) is assumed to have high species diversity, including a high number of endemic species. Floristic inventories of the forests in the Mamberamo area including the Foja Mountains around $1,000 \mathrm{~m}$ alt were produced by Mogea (2005), Takeuchi (2007, 2009 \& 2010) and Takeuchi \& Arifiani (2010). Heist et al. (2010) studied the lowland forests and related vegetation of Kwerba, on the Foja Foothills, and recorded common canopy trees and emergents in the primary forest, including Teijsmanniodendron bogoriense, T. hollrungii, Cleistanthus myrianthus, Intsia bijuga, Canarium maluense and Pometia pinnata. In the second highest stratum they recorded Anisoptera thurifera subsp. polyandra, Hopea novoguineensis, Vatica rassak, Pimelodendron amboinicum, Mastixiodendron pachyclados and Myristica fatua. Sambas (2014) studied the structure and floristic composition of lowland forest stands at Hotice and Kwerba and indicated that they were mixed forests with Teijsmanniodendron holophyllum and Anisoptera thurifera as the prevalent species but not distinctly dominant. The forest communities in the two sites may be designated as Teijsmanniodendron holophyllum-Anisoptera thurifera association that may be related to the associations in the Tembagapura area described by Shea et al. (1998).

The montane section above $1,000 \mathrm{~m}$ asl remained unexplored and untouched by human activities until a team of CII (Conservation International Indonesia) field naturalists from Indonesia, USA, England, and Australia carried out an expedition in November 2008 to undertake a comprehensive biodiversity survey of the Foja Mountains. One of us (AS) took part in the expedition. It is an isolated range in a little-studied corner of the tropical world of northern Papua Province (Beehler, 2007). Until 2008 we knew nothing about the floristic composition and structure of the montane forest in the Foja Mountains. The objective of the present study was to uncover and describe quantitatively for the first time the floristic composition and structure of the forest in the Foja Mountains. The study can provide scientific data for planning necessary actions in the long-term management of the reserve. Information on vegetation structure and species composition is needed in the development and management of conservation areas.

\section{MATERIALS AND METHODS}

\section{Study site}

Administratively the study area in the Foja Mountains is located in the Foja Wildlife Refuge (Suaka Margasatwa Foja) in the Kuerba Subdistrict, Kaso District, partly Mamberamo Raya Tengah Regency and partly Waropen Regency, Papua Province. Geographically the Foja Wildlife Refuge is located at 137 $54^{\prime} 33^{\prime \prime}-$ $138^{\circ} 15^{\prime} 32^{\prime \prime}$ East and 01 $29^{\prime} 59^{\prime \prime}-01^{\circ} 44^{\prime} 28^{\prime \prime}$ South. It encompasses several vegetation types ranging from lowland dryland forest, swamp forest, mixed swamp forest and lower montane forest to upper montane forest with the highest elevation of $\pm 2,193 \mathrm{~m}$ asl. A seasonally dry lake covered by herbaceous vegetation occurs within the montane forest. The forest in the reserve can be classified as a wet rain forest. The forest is a pristine primary forest, where there was no trace of previous disturbance resulting from human activities. Only natural disturbances, such as landslides on very steep slopes, may be observed in the area.

In the rainfall classification of Schmidt \& Ferguson (1951) the reserve falls within the rainfall type A (perhumid climate with percentage of the number of dry months over the number of wet months, $\mathrm{Q}=0-14.3 \%$ ). The nearest weather station to Foja Mountains is that at Wamena with a comparable altitude of $1,803 \mathrm{~m}$ asl. The rainfall and temperature data were available from Climate-Data (2017) and long-term rainfall data from Boerlage (1949). We constructed a climate diagram of Walter (1973) for Wamena (Fig. 1). The data showed that the wettest season with the highest rainfall occurred in February $( \pm 224 \mathrm{~mm})$ and March $( \pm 223 \mathrm{~mm})$ and the driest months with the lowest rainfall happened in June $( \pm 132 \mathrm{~mm})$ and July $( \pm 134 \mathrm{~mm})$. The daily temperature ranged from $25^{\circ} \mathrm{C}$ during day time to $13.5^{\circ} \mathrm{C}$ at night time. The weather during the study period in November 2008 was rainy and occasionally the area was covered by thick cloud. The humidity was $95 \%-$ $98 \%$ and the day-time temperature was $15^{\circ} \mathrm{C}-$ $18^{\circ} \mathrm{C}$.

Geographically the study site is located at $02^{\circ} 34.388^{\prime}$ 'South and $138^{\circ} 43.049^{\prime}$ 'East (Fig. 1), with an altitude of $1,710 \mathrm{~m}$ asl and a bird's eye view of the area is shown in Fig. 2. In general, the landscape consists of a montane forest zone on hilly topography with gentle to very steep slopes. The topography of the site where the study was undertaken was relatively flat with uneven ground surface. The soil is composed of a thin layer of humus overlying a porous greyish-brown layer, with $\mathrm{pH}$ of $4-4.5$ and in places is swampy and peaty. 


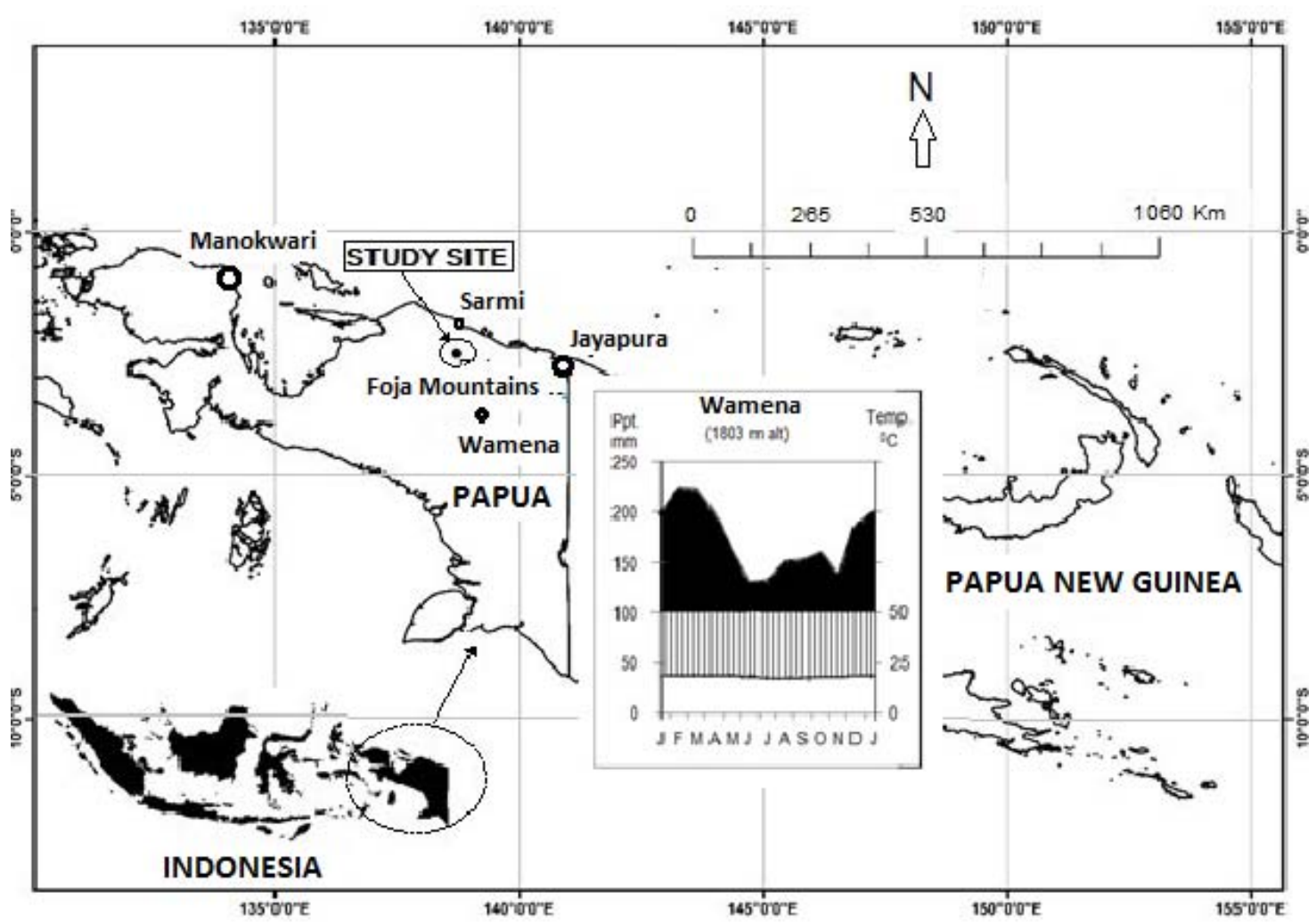

Fig. 1. Map of Papua indicating the study site at Foja Mountains, complemented with a Walter's climate diagram for Wamena, the nearest site having rainfall and temperature data. It shows that the area is everwet with mean monthly rainfall $\geq 100 \mathrm{~mm}$.

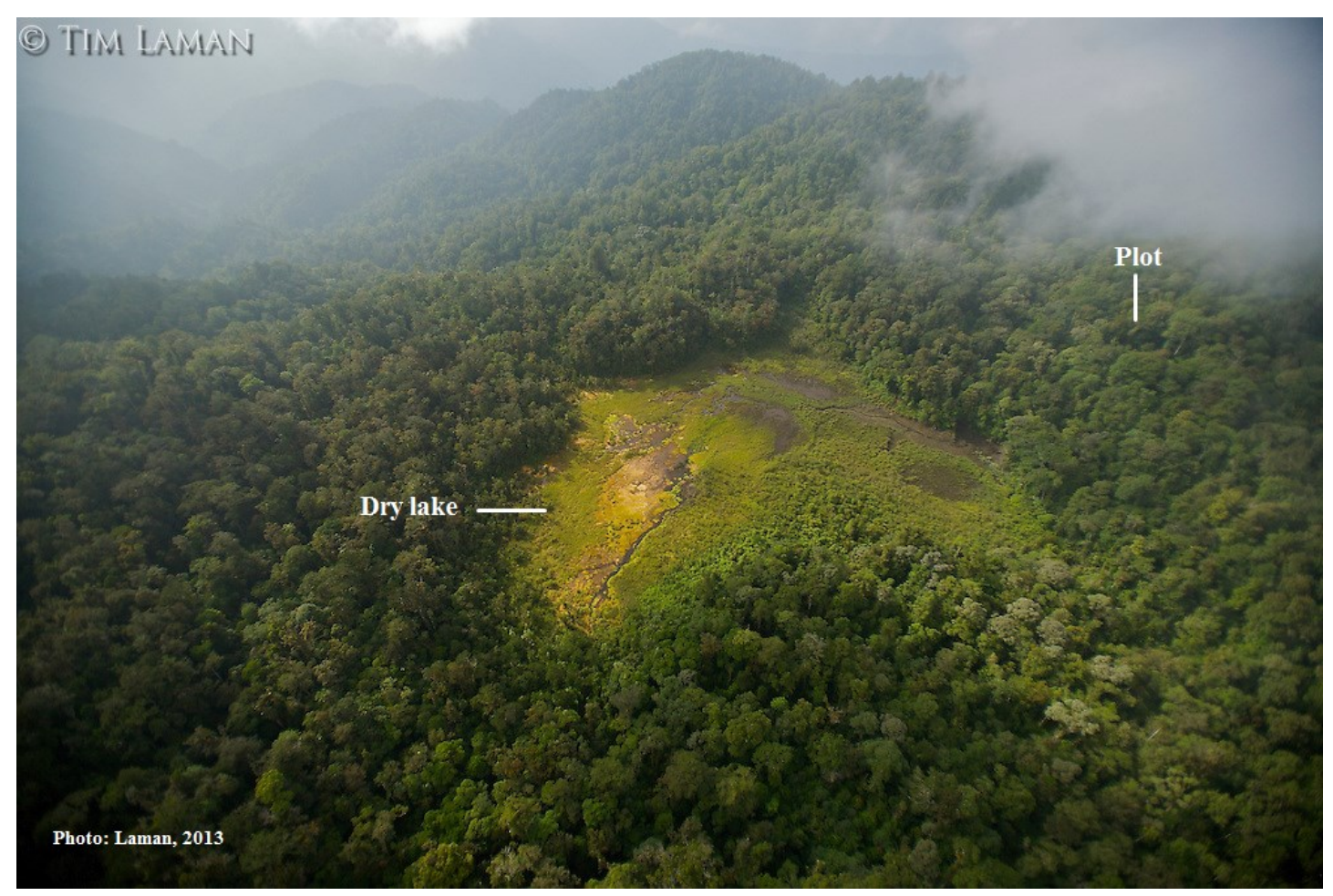

Fig. 2. Bird's eye view of the study site in the submontane forest near a seasonally dry lake in the Foja Mountains (After Foja Mountains - Images from Tim Laman's Wildlife Photo Archive_Page 2 - 201 MM744070618-00922.jpg https://goo.gl/images/iYcYiE accessed 29 May 2017; with permission). 
Geologically it consists of young tertiary rocks and sediments. The rock formation is composed of surficial sediments (alluvium, limestone and corals), sedimentary rocks, solidified rocks, tectonic (mixed) rocks and mud sediments. The area contains high mineral and energy resources, including copper and oil (Mampioper, 2009).

\section{Methods}

Field sampling was undertaken in the forest using the plot method (Cox, 1967; Mueller-Dombois \& Ellenberg, 1974). A plot of one hectare $(100 \mathrm{~m} \times 100 \mathrm{~m})$ was established subjectively in the floristically and structurally most representative area on a relatively gentle slope of $20-30 \%$ in the most accessible area (Fig. 2 ). The plot size is greater than the minimal area for montane forest of Indonesia (Kartawinata, 2005) and is even acceptable for describing a tropical lowland forest (Ashton, 1965). The plot was further divided into $100 \mathrm{sub-}$ plots of $10 \mathrm{~m} \times 10 \mathrm{~m}$ each (Kartawinata et al., 2004). Within each subplot all trees with DBH (Diameter at Breast Height) $\geq 10 \mathrm{~cm}$ were identified, their diameters measured and their positions recorded. Woody lianas with $\mathrm{DBH} \geq 10 \mathrm{~cm}$ were treated as trees. The measurement and estimation of total height and bole height were achieved by selecting several of the tallest trees in different sections of the plot whose total and bole heights could be easily measured accurately with a Haga altimeter. The selected tallest trees were then used as the reference trees in measurements of the others. In each subplot, the percentage of canopy gaps and the projected tree crown coverage were estimated. A simulated forest profile diagram for the plot was constructed using the method of Kartawinata et al. (2004) by plotting in a linear row the data on tree heights and tree numbers reflecting the sequence of field recording.

Herbarium specimens for each species within the plot were collected and identified at the Herbarium Bogoriense, Research Center for Biology-LIPI, Cibinong. The identity and nomenclature of each tree species followed the Tree flora of Indonesia: Check list for Irian Jaya (Whitmore et al., 1997), Flora Malesiana (Steenis et al., 1948-2013) and The Plant List (2017) .

We used Cox (1967) and Mueller-Dombois \& Ellenberg (1974) as applied by Rahmah et al. (2016), Purwaningsih et al. (2017) and Mansur \& Kartawinata (2017) for definition and calculation of density, frequency, basal area, and dominance. Density refers to the number of trees per unit area, based on counts in subplots. The number of trees per species was later calculated for the total area of the plot. The density of each species was formulated as the number of trees per hectare. The Relative Density (RD) for each species was determined as:

$$
R D=\frac{\text { number of trees of a species }}{\text { total number of trees }} \times 100 \%
$$

Frequency $(F)$ refers to the number of times a species occurs in a given number of subplots in the plot and was presented as a percentage of the total number of subplots. The Relative Frequency (RF) for each species was computed as:

$$
R F=\frac{\text { frequency of a species }}{\text { sum of frequency of all species }} \times 100 \%
$$

Dominance for trees generally relates to stem cover, which is the same as basal area. The basal area (BA) of a tree was calculated with the formula:

$$
B A=(1 / 2 d)^{2} \pi
$$

where $d=$ diameter, $\pi=$ constant value $(22 / 7$ or 3.14)

The Relative Dominance (RDo) was computed as:

$$
R D o=\frac{\text { dominance of a species }}{\text { dominance of all species }} \times 100 \%
$$

The sum of relative density, relative frequency, and relative dominance is usually used to indicate the importance of a species in a plot and are expressed in terms of their relative values. The Importance Value (IV) was then calculated with the formula:

$$
I V=R D+R F+R D o
$$

and the IV of a species reaches a maximum of 300 in the plot consisting of only one tree species.

Species diversity index was calculated using the formula of Shannon-Wiener ( $\left.\mathrm{H}^{\prime}\right)$ based on the number of individuals as follow:

$$
\mathrm{H}^{\prime}=-\Sigma \text { pi } \ln \text { pi }\left(\mathrm{H}^{\prime}=-\Sigma[\mathrm{ni} / \mathrm{N}] \ln [\mathrm{ni} / \mathrm{N}]\right)
$$

where $H^{\prime}$ = Shannon-Wiener's species diversity index

$\mathrm{pi}=\mathrm{ni} / \mathrm{N}$

$\mathrm{ni}=$ Number of individuals of the $\mathrm{i} t \mathrm{~h}$ species, in which $\mathrm{i}=1,2,3 \ldots \mathrm{n}$

$\mathrm{N}=$ Total number of individuals of all species.

The construction of the species-area curve was based on species data from 100 subplots nested within the plot, i.e. $100 \mathrm{~m}^{2}(10 \mathrm{~m} \times 10 \mathrm{~m}), 400 \mathrm{~m}^{2}$ $(20 \mathrm{~m} \times 20 \mathrm{~m}), 900 \mathrm{~m}^{2}(30 \mathrm{~m} \times 30 \mathrm{~m}), 10,000 \mathrm{~m}^{2}$ $(100 \mathrm{~m} \times 100 \mathrm{~m})$. We do not intend to specifically determine the minimal-area of sampling for the forest in the study area. The minimal area is 
usually determined by constructing a species-area curve to show a full representation of species when the objective is to obtain data using a single "minimal area" plot of the community (MuellerDombois \& Ellenberg, 1974). This approach is usually difficult to excercise in species-rich and complex tropical forests (Ashton, 1965; MuellerDombois \& Ellenberg, 1974), such as a lowland forest of Kalimantan where there is no indication of the curve to level-off of at the area of 10.5 ha (Kartawinata et al., 2008).

\section{RESULTS}

\section{Observations on habitat and general condition of the forest}

Field observations revealed that the forest was a pristine primary forest, where there was no trace of previous disturbance resulting from human activities. Only natural disturbances, such as land slides on very steep slopes, were observed in the area. The canopy cover in each subplot was $60 \%-80 \%$. In Fig. 11 the highlighted subplot 24 had a canopy cover of $30 \%$ and in the highlighted subplot 25 it was $50 \%$. The highlighted subplots $24,29,30,34$ and 35 were flooded. The highlighted subplot 25 indicates the canopy cover of $50 \%$ and that the forest ground was partially flooded and covered by Alocasia macrorrhizas (L.) G.Don (Araceae) which reached up to $\pm 1.5 \mathrm{~m}$ tall (Fig. $3)$. The soil was black and not stony.

Almost all trees in the forest were blanketed with mosses from the trunk bases to the twigs, hence it can be appropriately called a mossy forest. The area was so isolated that it could be reached only by using a helicopter that could land on the dry section of the lake occurring near the study site (Fig.1). There were open spaces, where the ground was covered by undergrowth (Fig. 4), including Strobilanthes sp. (Acanthaceae) on uninundated forest floor on highlighted subplots 24, 30, 34 and 35 in Fig. 11. Fallen dead trees were found on plot 50. Epiphytes on short trees were not abundant but included Dendrobium dekockii J.J.Sm. which grew together with moss (Usnea sp.). The low herbaceous and shrubby vegetation around the lake appeared to be interesting to investigate.

The topography of the study site was undulating but in general was more or less flat. Tree distribution in the plot was in general well dispersed. The mean number of trees per subplot in subplots $2-12$ was $7 \pm 2.44$. In Fig. 11, the topography of highlighted subplots $80,90,97,98$ 99 and 100 was sloping $\left(45^{\circ}-75^{\circ}\right)$, with the mean number of trees per subplot of $7 \pm 1.97$.

\section{Species composition}

In the one-hectare plot, we recorded 59 tree species with $\mathrm{DBH} \geq 10 \mathrm{~cm}$, belonging to 42 genera and 27 families, with total density of 693 and total basal area of $41.36 \mathrm{~m}^{2}$ (Table 1). Three trees could not be identified. Nothofagus rubra ( $\mathrm{IV}=47.89 ; \quad \mathrm{D}=142)$ and Parinari corymbosa (IV=40.53; $\mathrm{D}=89$ ) were the two leading dominants, hence the forest can be designated as the Nothofagus rubra-Parinari corymbosa association. They had a total density of 231 or $33.36 \%$ of the total in the plot and basal areas of $12.48 \mathrm{~m}^{2}(30.17 \%)$. The other leading species, having IV $>10$ were Myristica hollrungii, Platea latifolia and Lophopetalum torricellense (Table 1). They had a total density of $374(53.77 \%)$ and basal area of $24.37 \mathrm{~m}^{2}(58.92 \%)$. Myrtaceae were the richest family consisting of 12 species, while each of the remaining 26 families contained less than 6 species. Shannon-Wiener's diversity index was 3.22 and the evenness index were 0.79 .

The species-area curve (Fig. 5) shows that at $2,500 \mathrm{~m}^{2}$ it flattens up to $10,000 \mathrm{~m}^{2}$. It is safe to designate the minimal area of $5,000 \mathrm{~m}^{2}$.

We observed also IV $>5 \%$ in 11 families along with their relative values of density, frequency and dominance (Table 2). High density were recorded in Fagaceae (152 trees/ha), Chrysobalanaceae (89 trees/ha), Myristicaceae (55 trees/ha), Myrtaceae (58 trees/ha) and Icacinaceae (57 trees/ha). The lowest density ( 5 trees/ha) were recorded in Flacourtiaceae, Sterculiaceae, and Symplocaceae.

Species density, frequency and dominance in the plot is vary. Ten species with highest density, frequency, dominance, but they were in different orders (Table 3). Nothofagus rubra had the highest density dan highest dominance (142 trees/ha and $6.50 \mathrm{~m}^{2} /$ ha and Parinari corymbosa with the highest frequency $(\mathrm{F}=69 \%)$, while lowest density, distribution and dominance are four species found.

High frequency was observed in Fagaceae (69\%), Chrysobalanaceae (69\%) and Myrtaceae $(51 \%)$. The lowest frequency was observed in Symplocaceae (3\%).

The highest basal area was noted in Fagaceae $\left(7.48 \mathrm{~m}^{2} / \mathrm{ha}\right)$, Chrysobalanaceae $\left(5.98 \mathrm{~m}^{2} / \mathrm{ha}\right)$ and Myristicaceae $\left(4.32 \mathrm{~m}^{2} / \mathrm{ha}\right)$. The lowest basal area was noted in Symplocaceae $\left(0.05 \mathrm{~m}^{2} / \mathrm{ha}\right)$.

High importance values $(>20 \%)$ was observed in Fagaceae (53.23\%), Chrysobalanaceae $(40.53 \%)$, Myristicaceae $(26.43 \%)$, Myrtaceae (24.08\%) and Icacinaceae (22.35\%). The lowest importance value was observed in Symplocaceae $(4.47 \%)$.

\section{Structure}

Horizontal and vertical distribution, size, and density of trees define forest structure (Kershaw, 1964; Mueller-Dombois \& Ellenberg, 1974). The structure of forest in the plot is presented as graphs (Figs. 6, $7 \& 8$ ), simulated profile dia- 


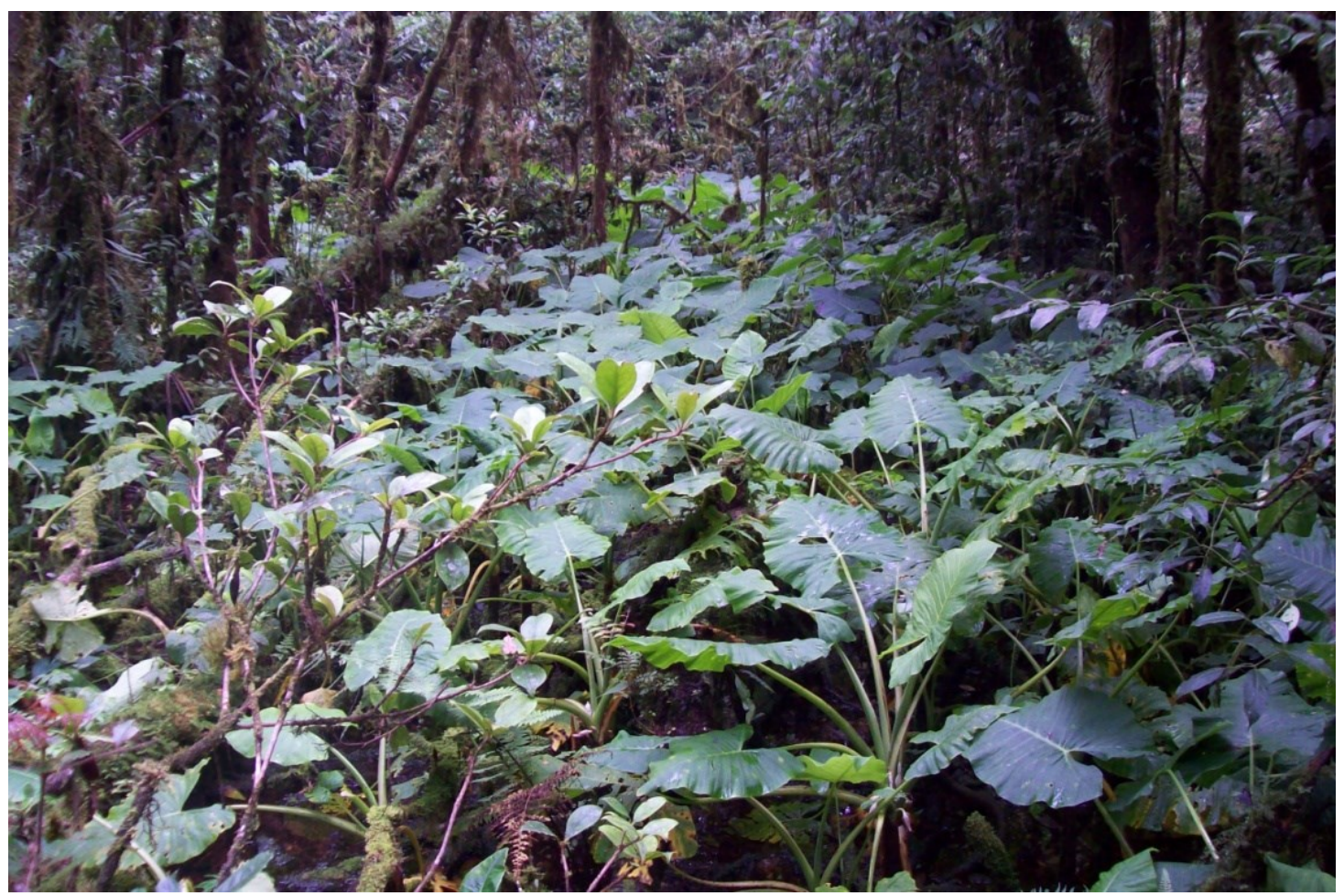

Fig. 3. A locasia macrorrhizos (Araceae) reaching $\pm 1.5 \mathrm{~m}$ tall on swampy forest floor within the plot (Photo: A. Sadili, 2008).

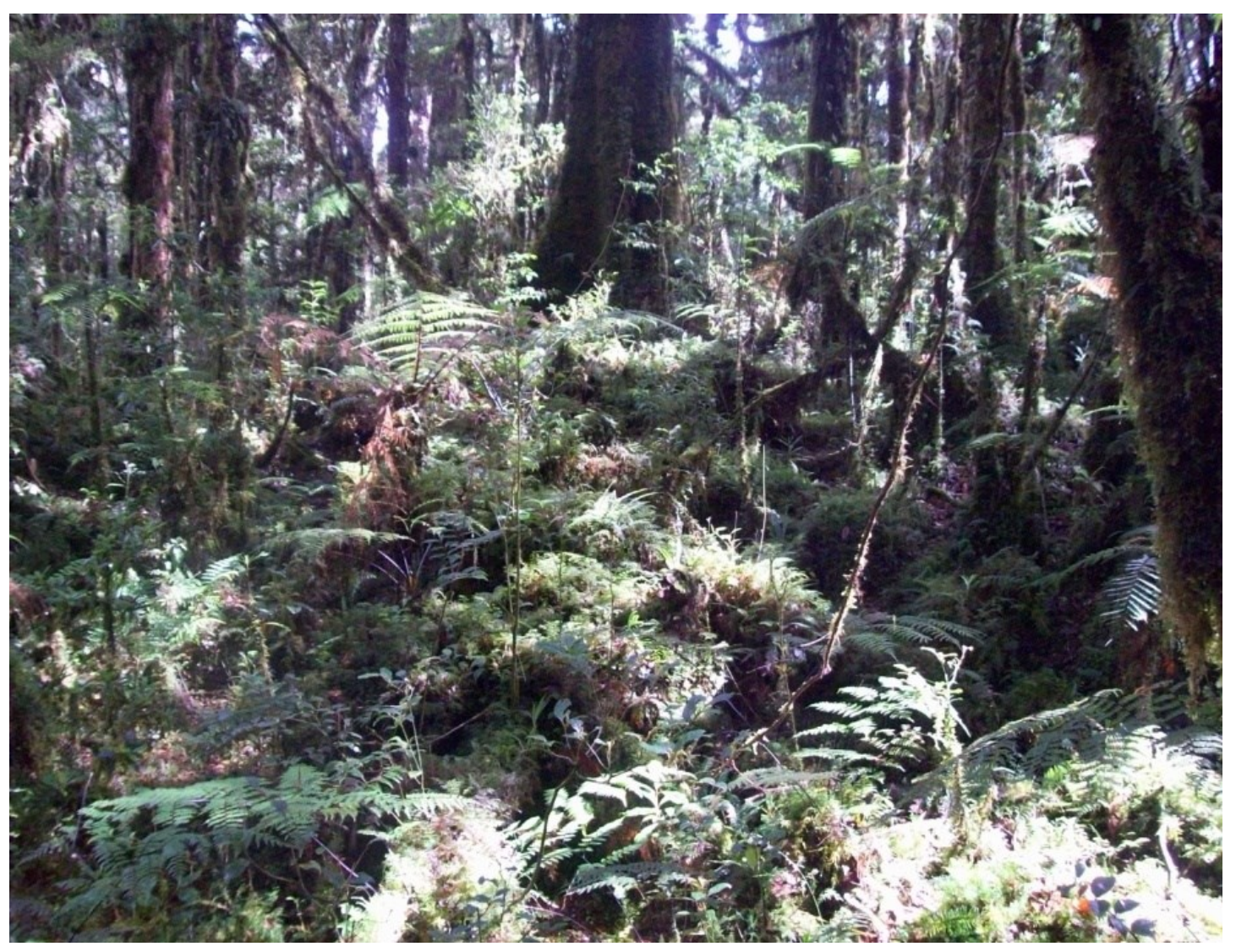

Fig. 4. Undergrowth vegetation of mixed species on uninundated forest floor within the plot (Photo: A. Sadili, 2008). 
Table 1. Density (D), frequency (F), basal area (BA) and importance value (IV) of trees $\geq 10 \mathrm{~cm}$ in the one hectare plot at the Foja Mountains, Papua. The species are arranged in descending order of IV.

\begin{tabular}{|c|c|c|c|c|c|}
\hline No & Species & D (Tree/ ha) & F (\%) & $\mathbf{B A}\left(\mathbf{m}^{2}\right)$ & IV (\%) \\
\hline 1 & Nothofagus rubra Steenis & 142 & 61 & 6.5 & 47.9 \\
\hline 2 & Parinari corymbosa (Blume) Miq. & 89 & 69 & 5.98 & 40.53 \\
\hline 3 & Myristica hollrungii Warb. & 53 & 40 & 4.23 & 25.55 \\
\hline 4 & Platea latifolia Blume & 57 & 40 & 2.67 & 22.35 \\
\hline 5 & Lophopetalum torricellense Loes & 33 & 27 & 3.99 & 19.59 \\
\hline 6 & $\begin{array}{l}\text { Elaeocarpus culminicola Warb. } \\
\text { Syzygium fibrosum (F.M. Bailey) T.G. Hartley \& }\end{array}$ & 13 & 13 & 1.52 & 8.04 \\
\hline 7 & L.M.Perry & 14 & 12 & 0.72 & 6.06 \\
\hline 8 & Carallia brachiata (Lour.) Merr. & 14 & 13 & 0.62 & 6.01 \\
\hline 9 & Garcinia sp. & 9 & 7 & 1.2 & 5.54 \\
\hline 10 & Aporosa longicaudata Kaneh. \& Hatus. ex Schot. & 15 & 13 & 0.35 & 5.5 \\
\hline 11 & Timonius timon (Spreng.) Merr. & 7 & 7 & 1.27 & 5.42 \\
\hline 12 & Lithocarpus sp. & 10 & 8 & 0.98 & 5.35 \\
\hline 13 & Cryptocarya brassii C.K.Allen & 8 & 6 & 1.05 & 4.84 \\
\hline 14 & Memecylon edule Roxb. & 11 & 11 & 0.45 & 4.78 \\
\hline 15 & Calophyllum excelsum Zoll. \& Moritzi & 11 & 9 & 0.56 & 4.67 \\
\hline 16 & Syzygium $\mathrm{sp}$. & 9 & 9 & 0.62 & 4.52 \\
\hline 17 & Nephelaphyllum sp. & 10 & 9 & 0.5 & 4.38 \\
\hline 18 & Cinnamomum sp. & 11 & 10 & 0.33 & 4.3 \\
\hline 19 & Fagraea elliptica Roxb. & 6 & 6 & 0.81 & 3.98 \\
\hline 20 & Dysoxylum sp. & 9 & 9 & 0.38 & 3.94 \\
\hline 21 & Litsea timoriana Span. & 5 & 5 & 0.75 & 3.49 \\
\hline 22 & Podocarpus neriifolius D.Don & 7 & 7 & 0.39 & 3.29 \\
\hline 23 & Eurya sp. & 9 & 7 & 0.23 & 3.2 \\
\hline 24 & Elaeocarpus oriomensis Weibel & 7 & 6 & 0.38 & 3.08 \\
\hline 25 & Turpinia sphaerocarpa Hassk. & 10 & 7 & 0.12 & 3.07 \\
\hline 26 & Palaquium sp. & 7 & 6 & 0.37 & 3.05 \\
\hline 27 & Syzygium laqueatum Merr. \& L.M.Perry & 9 & 7 & 0.1 & 2.88 \\
\hline 28 & Ficus sp. & 6 & 5 & 0.41 & 2.82 \\
\hline 29 & Glochidion novoguineense K.Schum. & 8 & 7 & 0.1 & 2.74 \\
\hline 30 & Rapanea leucantha K.Schum. & 7 & 7 & 0.1 & 2.59 \\
\hline 31 & Syzygium jambosoides (Lauterb.) Merr. \& L.M.Perry & 8 & 6 & 0.09 & 2.52 \\
\hline 33 & Artocarpus sp. & 6 & 6 & 0.17 & 2.43 \\
\hline 34 & Chisocheton lasiocarpus (Miq.) Valeton & 6 & 6 & 0.06 & 2.16 \\
\hline 35 & Calophyllum insularum P.F.Stevens & 2 & 2 & 0.61 & 2.15 \\
\hline 36 & Syzygium branderhorstii Lauterb. & 3 & 3 & 0.43 & 2.05 \\
\hline 37 & Madhuca sp. & 2 & 2 & 0.53 & 1.95 \\
\hline 38 & Polyosma illicifolia Blume & 6 & 5 & 0.05 & 1.94 \\
\hline 39 & Dacrycarpus imbricatus (Blume) de Laub. & 4 & 4 & 0.22 & 1.88 \\
\hline 40 & Casearia pachyphylla Gilg & 5 & 5 & 0.05 & 1.8 \\
\hline 41 & Sterculia sp. & 5 & 4 & 0.06 & 1.63 \\
\hline 42 & Metrosideros sp. & 4 & 4 & 0.07 & 1.51 \\
\hline 43 & Symplocos sp. & 5 & 3 & 0.05 & 1.42 \\
\hline 44 & Syzygium anomalum Lauterb. & 3 & 2 & 0.19 & 1.28 \\
\hline 45 & Ardisia forbesii S.Moore & 3 & 2 & 0.15 & 1.18 \\
\hline 46 & Syzygium phaeostictum Merr. \& L.M.Perry & 3 & 3 & 0.03 & 1.08 \\
\hline 47 & Unidentified & 3 & 3 & 0.02 & 1.06 \\
\hline 48 & $\begin{array}{l}\text { Glochidion molle Blume } \\
\text { Syzygium claviflorum (Roxb.) Wall. ex A.M.Cowan \& }\end{array}$ & 2 & 2 & 0.05 & 0.79 \\
\hline 49 & Cowan & 2 & 2 & 0.05 & 0.79 \\
\hline 50 & Croton laevifolius Blume & 2 & 2 & 0.02 & 0.72 \\
\hline 51 & Syzygium insulare Hartley \& L.M.Perry & 1 & 1 & 0.14 & 0.67 \\
\hline 52 & Knema sp. & 1 & 1 & 0.06 & 0.48 \\
\hline 53 & Myristica fatua Houtt. & 1 & 1 & 0.03 & 0.41 \\
\hline 54 & Polyosma integrifolia Blume & 1 & 1 & 0.03 & 0.41 \\
\hline 55 & Syzygium platycarpum (Diels) Merr. \& L.M. Perry & 1 & 1 & 0.02 & 0.38 \\
\hline 56 & Antidesma sp. & 1 & 1 & 0.01 & 0.36 \\
\hline 57 & Cryptocarya cordata Meisn. & 1 & 1 & 0.01 & 0.36 \\
\hline 58 & Macaranga fallacina Pax \& K.Hoffm. & 1 & 1 & 0.01 & 0.36 \\
\hline 59 & Syzygium antisepticum (Blume) Merr. \& L.M.Perry & 1 & 1 & 0.01 & 0.36 \\
\hline
\end{tabular}




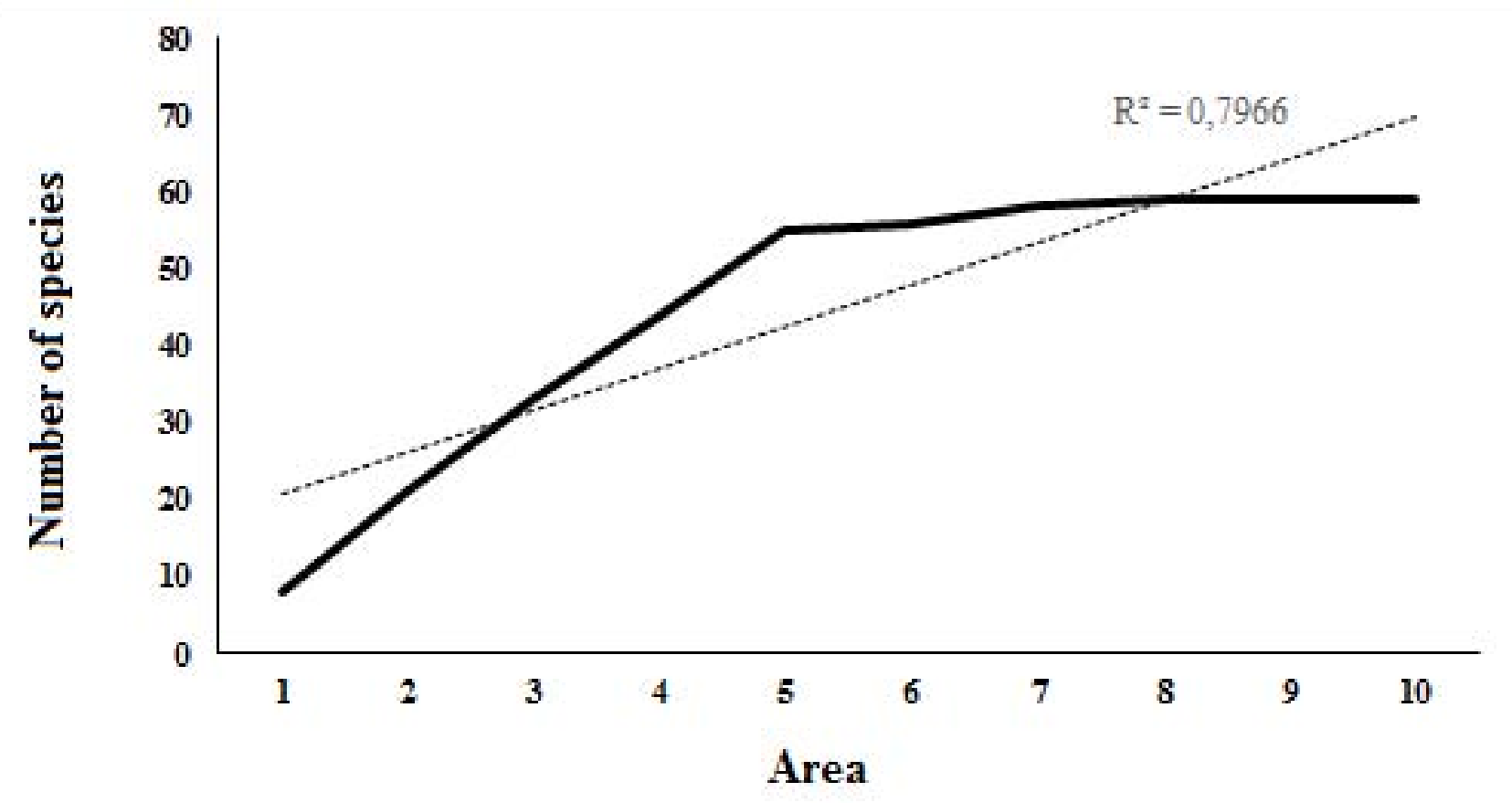

Fig. 5. Species-area curve of a one-hectare plot of forest at the Foja Mountains Papua. Area $1=100 \mathrm{~m}^{2}$; $2=400 \mathrm{~m}^{2} ; 3=900 \mathrm{~m}^{2} ; 4=1,600 \mathrm{~m}^{2} ; 5=2,500 \mathrm{~m}^{2} ; 6=3,600 \mathrm{~m}^{2} ; 7=4,900 \mathrm{~m}^{2} ; 8=6,400 \mathrm{~m}^{2} ; 9=8,100$ $\mathrm{m}^{2} ; 10=10,000 \mathrm{~m}^{2}$ (1 ha).

Table 2. Importance values (IV), relative density (RD), relative frequency (RF), and relative dominance (RDo) of 11 families having IV $>10 \%$ in the one-hectare plot of forest at Foja Mountains Papua.

\begin{tabular}{clcccc}
\hline No & Family & RD (\%) & $\begin{array}{c}\text { RF } \\
\mathbf{( \% )}\end{array}$ & $\begin{array}{c}\text { RDo } \\
\mathbf{( \% )}\end{array}$ & IV \\
\hline 1 & Fagaceae & 21.93 & 13.22 & 18.08 & 53.23 \\
2 & Chrysobalanaceae & 12.84 & 13.22 & 14.47 & 40.53 \\
3 & Myristicaceae & 7.94 & 8.05 & 10.45 & 26.43 \\
4 & Myrtaceae & 8.37 & 9.77 & 5.94 & 24.08 \\
5 & Icacinaceae & 8.23 & 7.66 & 6.46 & 22.35 \\
6 & Celastraceae & 4.76 & 5.17 & 9.64 & 19.57 \\
7 & Lauraceae & 3.61 & 4.21 & 5.18 & 13.00 \\
8 & Clusiaceae & 3.17 & 3.45 & 5.74 & 12.36 \\
9 & Meliaceae & 3.90 & 4.98 & 2.47 & 11.35 \\
10 & Elaeocarpaceae & 2.89 & 3.64 & 4.58 & 11.10 \\
11 & Euphorbiaceae & 4.18 & 4.98 & 1.28 & 10.45 \\
\hline
\end{tabular}


Table 3. Ten species with highest density, frequency, and basal area; and four species with lowest density, frequency and basal area in one-hectare plot of forest in Foja Mountains.

\begin{tabular}{|c|c|c|}
\hline & Species group & Species \\
\hline a. & $\begin{array}{l}\text { Ten species with highest } \\
\text { density (trees/ha) }\end{array}$ & $\begin{array}{l}\text { Nothofagus rubra (142), Parinari corymbosa (89), Platea } \\
\text { latifolia (57), Myristica hollrungii (53), Lophopetalum } \\
\text { torricellense (33), Aporosa longicaudata (15), } \\
\text { Syzygium fibrosum (14), Carallia brachiata (14), } \\
\text { Elaeocarpus culminicola (13) and Memecylon edule (11). }\end{array}$ \\
\hline b. & $\begin{array}{l}\text { Ten species with highest } \\
\text { frequency }(\%)\end{array}$ & $\begin{array}{l}\text { Parinari corymbosa (69), Nothofagus rubra (61), Platea } \\
\text { latifolia (40), Myristica hollrungii (40), Lophopetalum } \\
\text { torricellense (27), Aporosa longicaudata (13), } \\
\text { Carallia brachiata (13), Elaeocarpus culminicola (13), } \\
\text { Syzygium fibrosum (12) and Memecylon edule (11). }\end{array}$ \\
\hline c. & $\begin{array}{l}\text { Ten species with highest } \\
\text { basal area }\left(\mathrm{m}^{2}\right)\end{array}$ & $\begin{array}{l}\text { Nothofagus rubra }(6.50), \text { Parinari corymbosa }(5.98) \text {, } \\
\text { Myristica hollrungii }(4.23) \text {, Lophopetalum torricellense (3.99), } \\
\text { Platea latifolia }(2.67) . \text { Elaeocarpus culminicola }(1.52) . \\
\text { Timonius timon (1.27), Garcinia sp. }(1.20) \text {, Cryptocarya } \\
\text { brassii (1.05) and Lithocarpus sp. }(0.98) \text {. }\end{array}$ \\
\hline d. & $\begin{array}{l}\text { Four species with lowest } \\
\text { density, frequency, and } \\
\text { basal area }\end{array}$ & $\begin{array}{l}\text { Antidesma sp., Cryptocarya caudata, Macaranga fallacina, and } \\
\text { Syzygium antisepticum }\end{array}$ \\
\hline
\end{tabular}

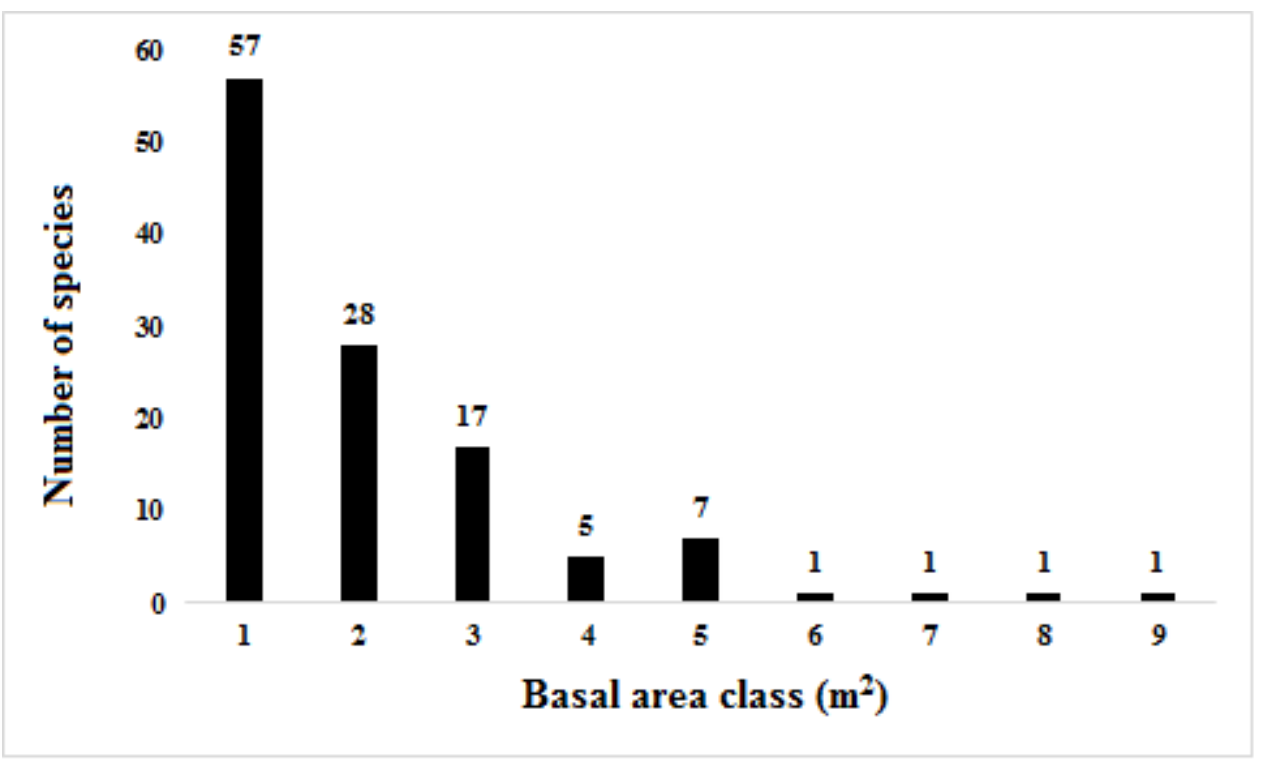

Fig. 6. The relationships between the number of species and basal area classes in the lower montane forest at Foja Mountains. Basal area class $\left(\mathrm{m}^{2}\right): 1=0.01-0.09 ; 2=0.10-0.19 ; 3=0.20-0.29 ; 4=0.30-0.39$; $5=0.40-0.49 ; 6=0.50-0.59 ; 7=0.60-0.69 ; 8=0.70-0.79$. 


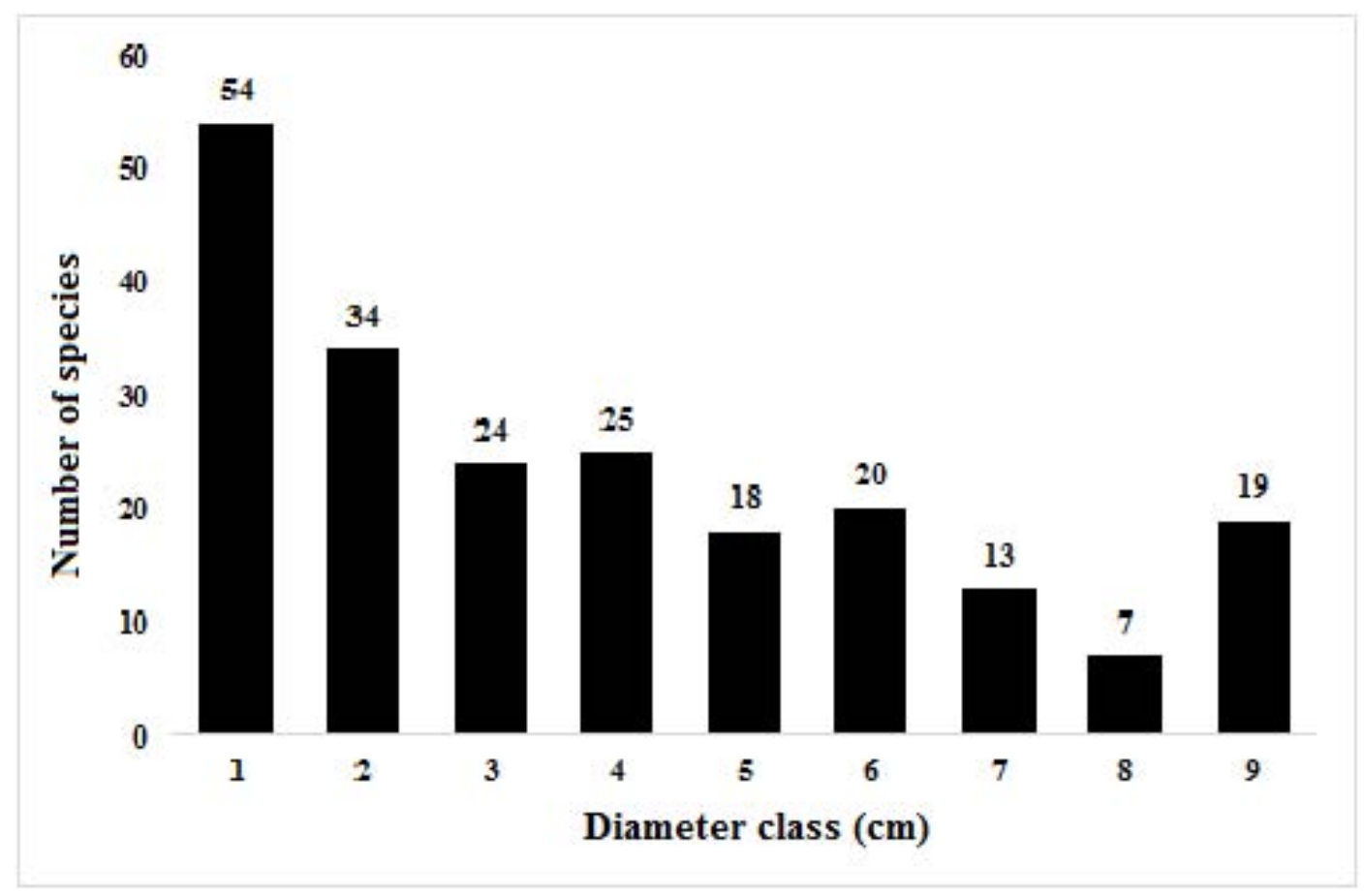

Fig. 7. The relationships between the number of species and diameter classes in the forest of Foja Mountains. The diameter classes: $1=10-14.9 \mathrm{~cm} ; 2=15-19.9 \mathrm{~cm} ; 3=20-24.9 \mathrm{~cm} ; 4=25-29.9 \mathrm{~cm} ; 5=30$ $34.9 \mathrm{~cm} ; 6=35-39.9 \mathrm{~cm} ; 7=40-44.9 \mathrm{~cm} ; 8=45-49.9 \mathrm{~cm}$; and $9 \geq 50 \mathrm{~cm}$.

grams (Fig. 9) and a photo (Fig. 10). Fig. 11 shows the map of ground distribution of all trees and Fig. 12 shows the map of ground distribution of the dominant species Nothofagus rubra and Parinari corymbosa. Density, dominance and frequency of each species vary. The total density of the entire plot was 693 trees/ha with the mean density of $7 \pm 2.46$ trees/subplot. The highest density as listed in Table 1 and Table 3a were recorded in Nothofagus rubra (142 trees/ha), Parinari corymbosa (89 trees/ha), Platea latifolia (57 trees/ha) and Myristica hollrungii (53 trees/ha). Density of one tree/ha and absolute frequency of $1 \%$ occurred in nine species including Antidesma sp., Cryptocarya caudata, Knema sp., Macaranga fallacina, Myristica fatua, Polyosma integrifolia, Syzygium anti-septicum, Syzygium insulare and Syzygium platycarpum (Table 1) with the mean frequency of the species being $5 \pm 1.88 \%$. The highest frequency was recorded in Parinari corymbosa $(69 \%)$ as in Table $3 b$.

The relationships between species and basal areas are presented in Fig. 6 which are definitely related to those between species and diameter classes as presented in Fig. 7. Fig. 8. shows the relationships between the number of trees and diameter classes.
Total BA was $\pm 41.36 \mathrm{~m}^{2} /$ ha and the mean was $0.41 \pm 0.29 \mathrm{~m}^{2} /$ subplot. The highest BA was recorded in Nothofagus rubra $\left(6.50 \mathrm{~m}^{2} / \mathrm{ha}\right)$, Parinari corymbosa $\left(5.98 \mathrm{~m}^{2} / \mathrm{ha}\right)$ and Myristica hollrungii $\left(4.23 \mathrm{~m}^{2} / \mathrm{ha}\right.$ ) (Table 3c). The lowest BA $\left(0.01 \mathrm{~m}^{2} / \mathrm{ha}\right)$ was recorded in Cryptocarya caudata, Syzygium antisepticum, Antidesma sp. and Macaranga fallacina (Table 1 and Table 3d).

A simulated forest profile diagram (Fig. 9) shows four strata (A, B, C \& D). The mean total tree height was $15.26 \pm 5.71 \mathrm{~m}$ and the mean bole height was $9.65 \pm 4.90 \mathrm{~m}$. The A stratum consisted of three emergent tree species comprising Nothofagus rubra, Platea latifolia, and Cinnamomum sp. The B stratum which constituted the upper canopy with the height of 20-29.9 m was composed of 169 trees $(24.39 \%)$ representing 41 species $(69.49 \%)$. The prevalent species, each re-presented by more than 10 trees included $N$. rubra (40 trees), P. corymbosa (20 trees), $M$. hollrungii (14 trees) and P. latifolia (10 trees). The $\mathrm{C}$ stratum with the height of 10-19.9 m formed the middle-level canopy and consisted of 408 trees $(58.87 \%)$ and 51 species $(86.44 \%)$. The prevalent species. each represented by more than 10 trees included $N$. rubra (88 trees), $P$. corymbosa (52 trees), M. hollrungii (36 trees), P. latifolia (30 trees), Lophopetalum torricellense (19 trees), and Carallia brachiata (12 trees). The 


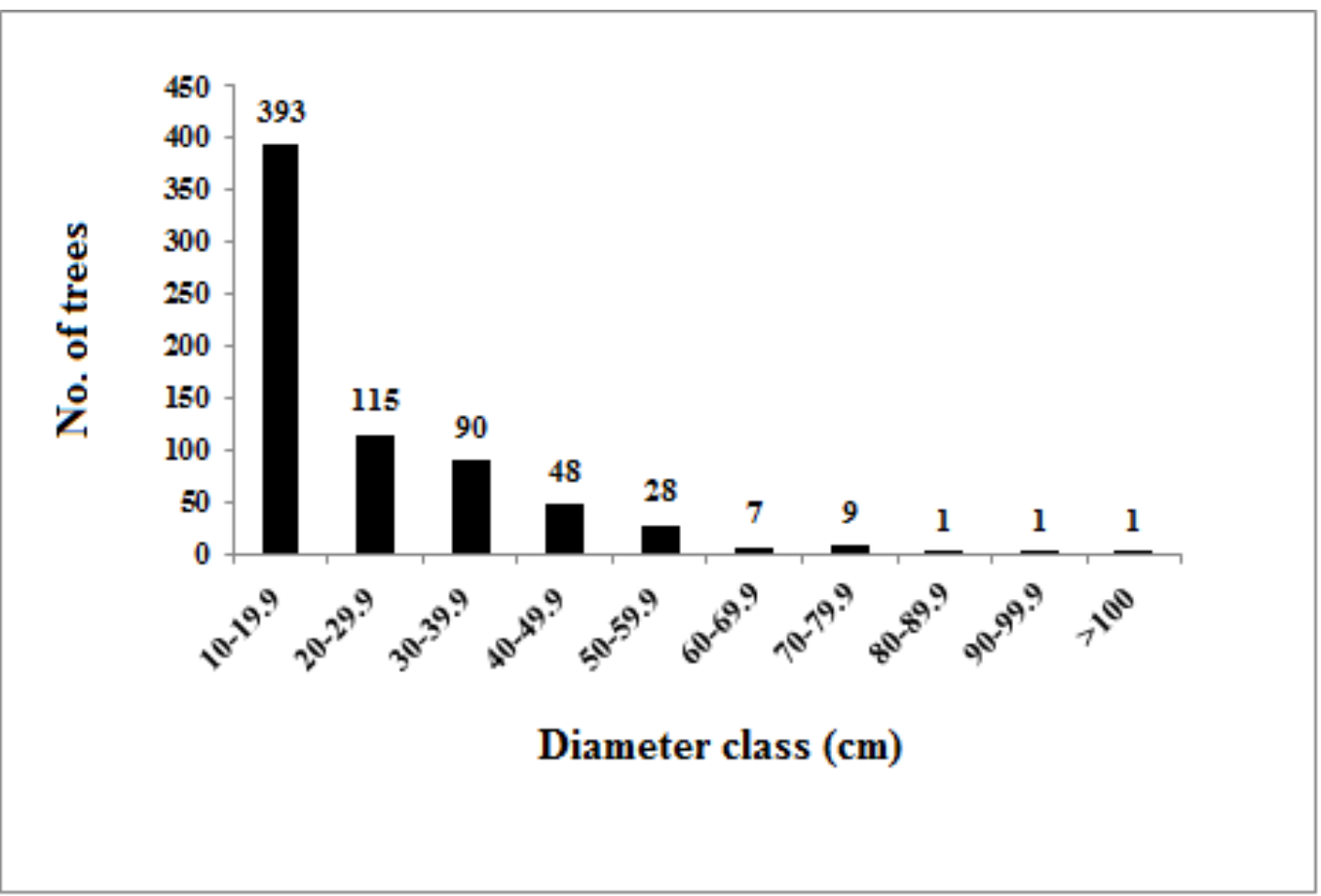

Fig. 8. The relationships between the number of trees and diameter classes in the lower montane forest at Foja Mountains.

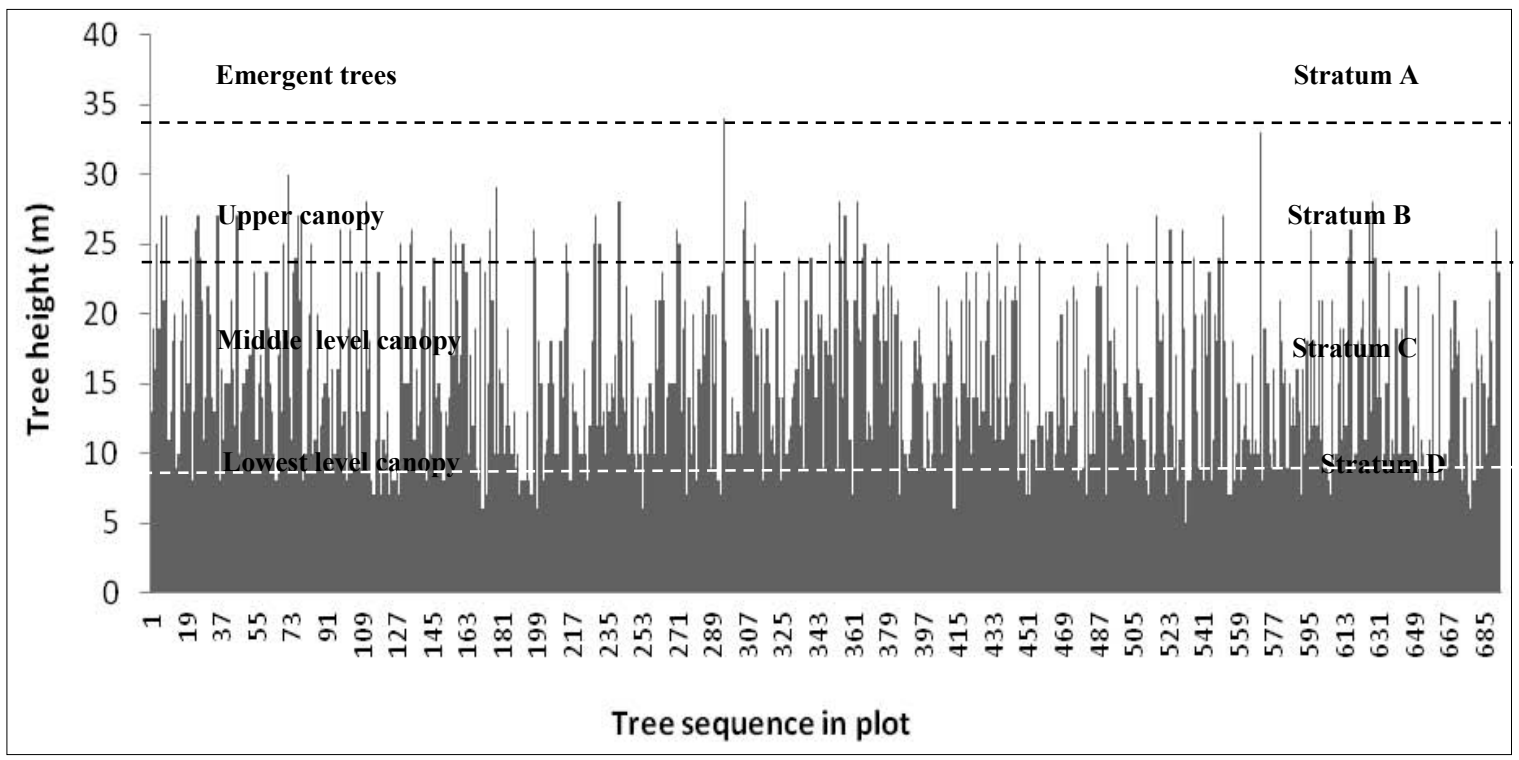

Fig. 9. A simulated forest profile diagram based on the tree height and sequential tree positions from tree no 1 in $1^{\text {st }}$ subplot up to the tree no. 693 in $100^{\text {th }}$ subplot in the one-hectare plot at Foja Mountains. It shows four strata: Stratum A (Emergent layer), Stratum B (Upper canopy), Stratum C (Middle level canopy) and Stratum D (Lower level canopy). 


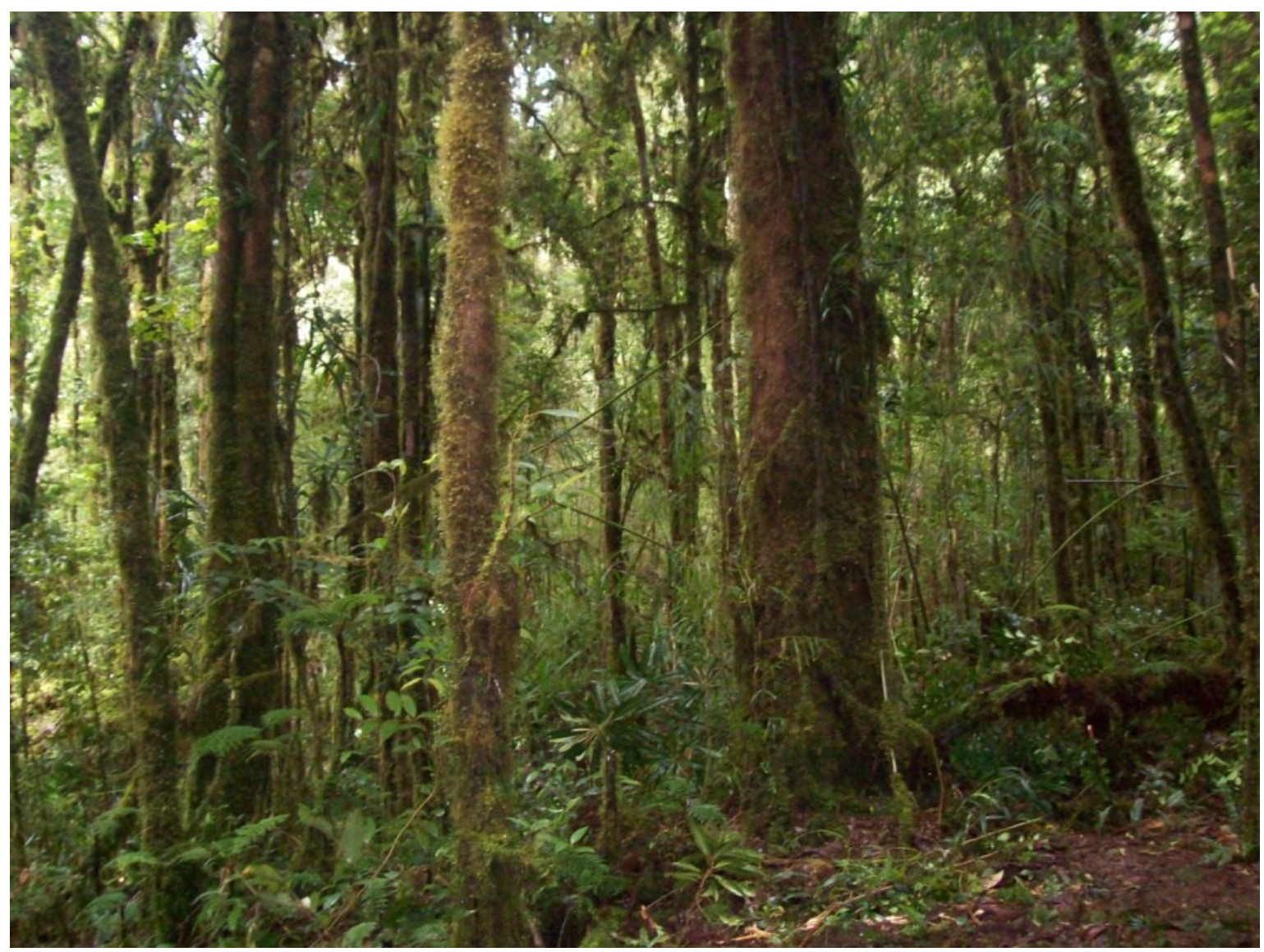

Fig. 10. The forest stand in the plot at the lower montane forest of the Foja Mountains, Papua showing dense structure with Nothofagus rubra and Parinari corymbosa as the dominant species (Photo: A. Sadili, 2008).

D stratum with height of 5-9.9 m constituted the lowest level canopy and consisted of 113 trees $(16.31 \%)$ and 34 species $(57.63 \%)$. The prevalent species, each represented by more than 10 trees, included $P$. corymbosa (17 trees), P. latifolia (16 trees) and $N$. rubra (13 trees).

\section{Species Regeneration}

The process of species regeneration in tropical forests is complex as it depends on a variety of factors including the fortuitous formation of natural gaps (Richards, 1996; Whitmore, 1984). Regeneration may be indicated by a complete profile of size class distribution from seedlings to trees with largest diameters. Size-class distributions, however, depend on growth and mortality (Jones, 1950 cited by Richards, 1996) and may be related to site conditions as well as to the occurrence of natural or artificial disturbances in the past (Richards, 1996).

Regeneration is a mechanism of an organism to maintain and perpetuate its existence, which in a forest stand can be reflected by the number of individuals along the gradient of diameter classes and height stratification. In the present study data on seedlings and saplings (diameter $<10 \mathrm{~cm}$ ) were not available and we recorded only trees with DBH $\geq 10 \mathrm{~cm}$ (Table 4). Based on the diameter class distribution we may assume and infer the status of regeneration of the species. In Table 4, the species were grouped according to diameter class distribution. Group 1 consisted of two species, Lophopetalum torricellense and Syzygium fibrosum. The species have been regenerating and are assumed to have reached a mature state in the forest. Group 2 consisted of species that could reach the maximum diameter of up to $79.9 \mathrm{~cm}$ and the density of trees in each diameter class were mostly less than nine. The most notable species in Group 2 were Parinari corymbosa and Platea latifolia. The density of these species in diameter classes of $10-20 \mathrm{~cm}$ to $40-50 \mathrm{~cm}$ was high, indicating that they were regenerating well. Other species were also regenerating but with low intensity. Group 3 consists of the species that have reached a diameter of less than $69.9 \mathrm{~cm}$ and they were regenerating but with low density, except for Myristica hollrungii. This species had a high density (51) in the diameter class of 10-19.9 $\mathrm{cm}$ indicating better regeneration than the other species. Group 4 contains species that reached the maximum diameters of $39.9 \mathrm{~cm}$. 


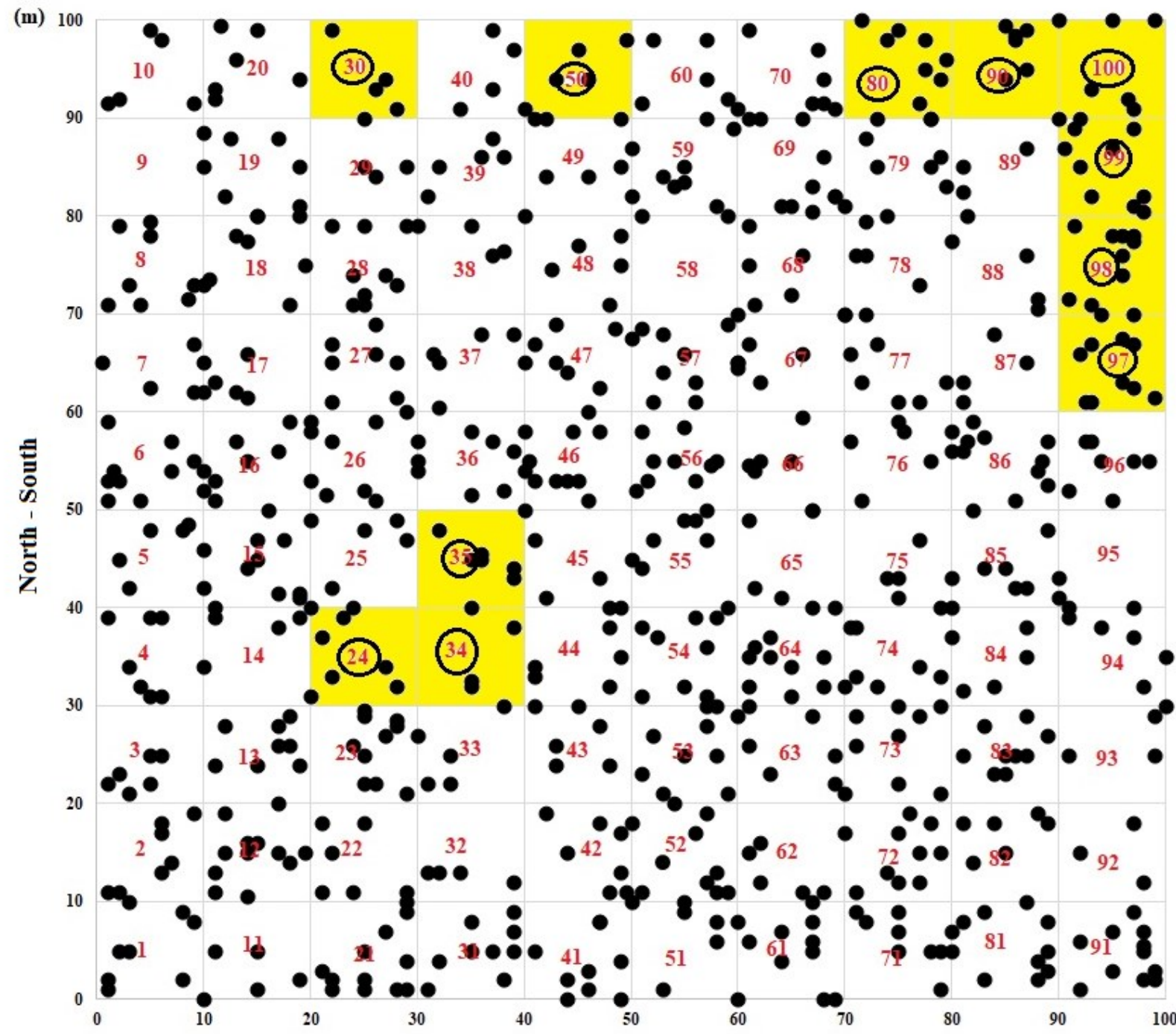

East - West

Fig. 11. The ground distribution of dense trees in the one-hectare plot in the lower montane forest of the Foja Mountains, Papua. The canopy cover in the highlighted subplot no 24 were $30 \%$ and in subplot 25 were $50 \%$. In the highlighted subplots $24,29,30,34,35$ the mean number of trees per subplot was $7 \pm$ 2.44. On highlighted subplots $80,90,97,98,99$ and 100 the topography was sloping $\left(45^{\circ}-75^{\circ}\right)$ with the mean number of trees per subplot of $7 \pm 1.97$. The highlighted subplots 24, 30, 34 and 35 were open and the ground was inundated and covered with Strobilanthes sp. (Acanthaceae). Fallen dead trees were found on highlighted subplot 50 . 


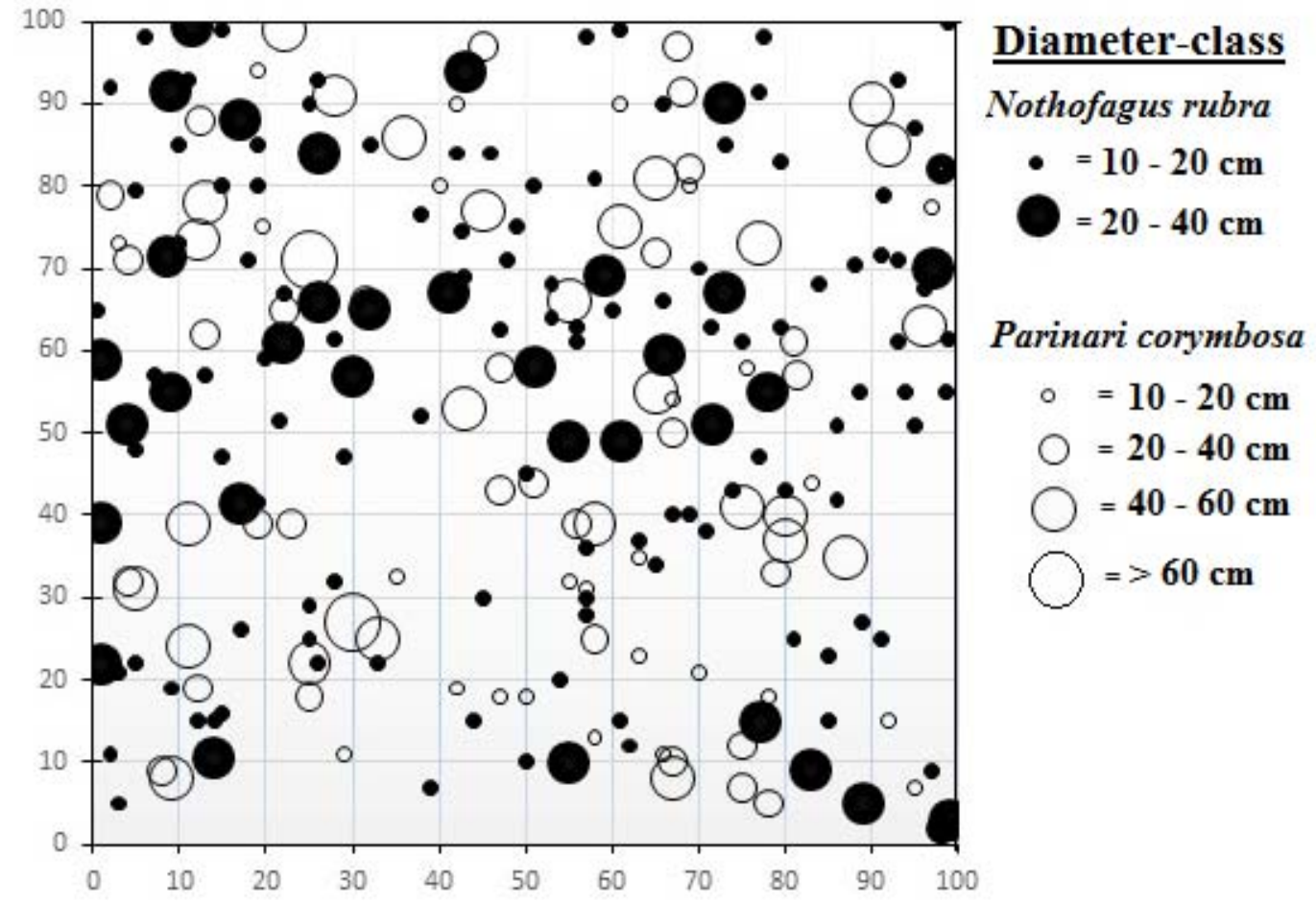

Fig. 12. Distribution of the two dominant species (Nothofagus rubra and Parinari corymbosa) in the onehectare plot in the lower montane forest of Foja Mountains, Papua.

Except for Nothofagus rubra, they are regenerating but with low density. Nothofagus rubra, the dominant species in the plot was regenerating well as indicated by high density in the diameter classes of $10-19.9 \mathrm{~cm}$ and $20-29.9 \mathrm{~cm}$. Group 5 represents species present only in the diameter class 10-19.9 $\mathrm{cm}$ with low density. They consisted of small trees and shrubs. Group 6 contains species that were not present in the 10-19.9 cm diameter class indicating no regeneration and will perhaps disappear from the plot in the future.

\section{DISCUSSION}

In the classification schemes of Johns et al. (2007) and Kartawinata (2013), the forest at the Foja Mountains definitely belongs to the lower montane forest. In the Foja Mountains, Nothofagus rubra was dominant in the forests with dry to swampy habitats. It is one of the tallest trees but not the largest in the forest. Johns et al. (2007) and Shea et al. (1998), however, did not indicate that $N$. rubra was a dominant species in their accounts of montane forests of Papua. The forest at Foja Mountains was designated as the Nothofagus rubra-Parinari corymbosa association.

Nothofagus in New Guinea is represented by 13 species (Soepadmo, 1972). They constitute important species that can dominate montane forests at $850-2,980 \mathrm{~m}$ asl, with varying distribution (Johns et al., 2007; Paijmans, 1976; Soepadmo, 1972), N. flaviramea, N. starkenborghii, N. rubra, N. carri, and N. crenata occur at $900-2,200 \mathrm{~m}$ asl, $N$. brassii, $N$. perryi and $N$. grandis are abundant at $1,500-2,500 \mathrm{~m}$ asl while N. pullei spreads up to $>2,800 \mathrm{~m}$ asl They form communities with different species combinations. At 2,300 m asl Nothofagus spp. often grow in association with Castanopsis acuminatissima or Lithocarpus. At high elevation Nothofagus spp. grow together with Phyllocladus hypophyllus and are associated with Dacrydium and Papuacedrus in wet and cold habitats. On a wider range Soepadmo (1972) noted that N. rubra occurs in New Guinea, but primarily in Papua, on very poor boggy and shrubby heathlands at $1,800 \mathrm{~m}$ asl, boggy forest on exposed ridges or summits up to 2,150 m asl, in stunted open Dacrydium forest at $850 \mathrm{~m}$ asl and in mossy forest at $950-2,850 \mathrm{~m}$ asl such as in Habbema (Brass, 1941; Keim et al. unpublished, 2018). It was further recorded as a common species often abundant on the Arfak Mountains and Wissel Lake and a dominant species in Castanopsis forest on the Cyclop Mountains (Johns et al., 2007).

Dieback occurs in Nothofagaceae, especially Nothofagus brassii and N. pullei in Habbema (Keim et al., unpublished, 2018), but there was no 
Table 4. Diameter class distribution of species with density $>10$ reflecting the regeneration status of the forest.

Diameter class (cm.)

$\begin{array}{lllllllllll}\text { Species } & 10-19.9 & 20-29.9 & 30-39.9 & 40-49.9 & 50-59.9 & 60-69.9 & 70-79.9 & 80-89.9 & 90-99.9 & >100\end{array}$

GROUP 1

Syzygium fibrosum

$\begin{array}{llllll}9 & 4 & 8 & 3 & 5 & 2\end{array}$

GROUP 2

Parinari corymbosa

29

Platea latifolia

Carallia brachiata

Calophyllum excelsum

Artocarpus sp.

Cryptocarya brassii

Syzygium leptanthum

$\begin{array}{lllll}4 & 3 & 2 & 2 & 1\end{array}$

2

1

GROUP 3

Myristica hollrungii

Memecylon edule

Nephelaphyllum sp.

Aporosa longicaudata

29
15

$13 \quad 18$

9

$\begin{array}{ll} & 2 \\ 1 & 1 \\ 1 & 1 \\ & 1 \\ & 1 \\ & 1 \\ & 1 \\ & \\ & \\ & \end{array}$

Timonius timon

Polyosma illicifolia

Garcinia sp.

Rapanea leucantha

Rapanea leucantha

Lithocarpus sp.

Rapanea leucantha

Ficus sp.

Symplocos sp.

$\begin{array}{lll}7 & 2 & 3\end{array}$

93

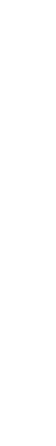


Table 4. (continued)

\begin{tabular}{|c|c|c|c|c|c|c|c|c|c|c|}
\hline \multirow{2}{*}{ Species } & \multicolumn{10}{|c|}{ Diameter class (cm.) } \\
\hline & $10-19.9$ & $20-29.9$ & $30-39.9$ & $40-49.9$ & $50-59.9$ & $60-69.9$ & $70-79.9$ & $80-89.9$ & $90-99.9$ & $>100$ \\
\hline Dysoxylum sp. & 4 & 3 & 2 & & & & & & & \\
\hline Glochidion novoguineense & 3 & 3 & 2 & & & & & & & \\
\hline Chisocheton lasiocarpus & 3 & 1 & 2 & & & & & & & \\
\hline Metrosideros sp. & 2 & 1 & 1 & & & & & & & \\
\hline Litsea timoriana & 2 & 2 & 1 & & & & & & & \\
\hline Podocarpus neriifolius & 1 & 2 & 4 & & & & & & & \\
\hline Unidentified & 1 & 1 & 1 & & & & & & & \\
\hline Cinnamomum sp. & 9 & & 2 & & & & & & & \\
\hline Elaeocarpus oriomensis & 6 & & 1 & & & & & & & \\
\hline Fagraea elliptica & 5 & & 1 & & & & & & & \\
\hline Sterculia sp. & 3 & 2 & & & & & & & & \\
\hline Croton laevifolius & 1 & 1 & & & & & & & & \\
\hline \multicolumn{11}{|l|}{ GROUP 5} \\
\hline Astronia spectabilis & 4 & & & & & & & & & \\
\hline Dacrycarpus imbricatus & 4 & & & & & & & & & \\
\hline Syzygium anomalum & 3 & & & & & & & & & \\
\hline Syzygium phaeostictum & 3 & & & & & & & & & \\
\hline Ardisia forbesii & 3 & & & & & & & & & \\
\hline Syzygium branderhorstii & 3 & & & & & & & & & \\
\hline Glochidion molle & 2 & & & & & & & & & \\
\hline Madhuca sp. & 2 & & & & & & & & & \\
\hline Antidesma sp. & 1 & & & & & & & & & \\
\hline Syzygium platycarpum & 1 & & & & & & & & & \\
\hline Cryptocarya caudata & 1 & & & & & & & & & \\
\hline Knema sp. & 1 & & & & & & & & & \\
\hline Polyosma integrifolia & 1 & & & & & & & & & \\
\hline Macaranga fallacina & 1 & & & & & & & & & \\
\hline \multicolumn{11}{|l|}{ GROUP 6} \\
\hline Eurya sp. & & 3 & 3 & 3 & & & & & & \\
\hline Myristica fatua & & 1 & & & & & & & & \\
\hline Syzygium antisepticum & & 1 & & & & & & & & \\
\hline Syzygium insulare & & 1 & & & & & & & & \\
\hline
\end{tabular}




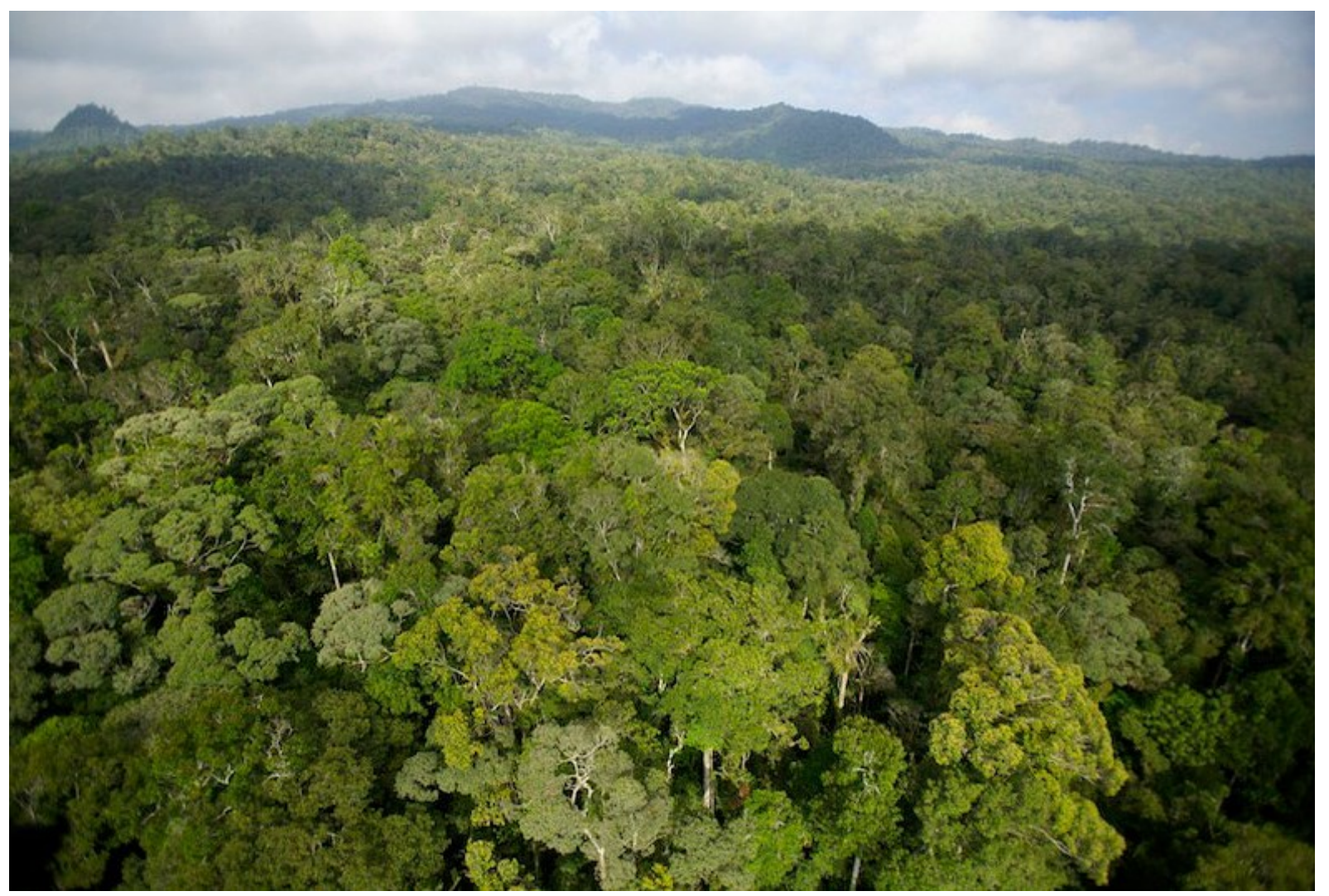

Fig. 13. Bird's eye view of the montane forest on more or less flat topography at the Foja Mountains (After Laman, with permission).

indication of occurrence on $N$. rubra in the Foja Mountains. Dieback is "an episodic event characterized by premature, progressive loss of tree and stand vigour and health over a given period without obvious evidence of a single clearly identifiable causal factor such as physical disturbance or attack by an aggressive disease or insect" (Ciesla \& Donaubauer, 1994). It is a part of forest dynamics involving complex interaction between physical and biotic factors and is initiated by sudden trigger, including drought, flood and wind (Mueller-Dombois, 1983 \& 1986).

The species richness [i.e. number of species in a sampling unit (McCune \& Grace, 2002)] and tree density in the forest of the Foja Mountains were lower than in several lowland forests of Papua, Sulawesi, Kalimantan and Sumatra and in the lower montane forest in Java (Fig. 13). Tree density in the present study was comparable to those in the montane forests in Wamena, Papua and in Gede-Pangrango National Park in Java. The situation supports the contention that species richness decreases as the elevation increases (Richards 1996; Whitmore, 1984).

It is clear that the forest under investigation had low species richness. The Shannon-Wiener's diversity index $\mathrm{H}^{\prime}=3.22$, which in the criteria of Barbour et al. (1987) can approach a high value of 4 . This is comparable to that of the lower mon- tane forest at the Gede-Pangrango National Park, West Java, where the diversity index $\mathrm{H}^{\prime}=3.39$ (Zuhri \& Mutaqin, 2011). It is much higher than that of the lower montane forest at Ceremai National Park which has a diversity index H' $=2.66$ (Purwaningsih \& Yusuf, 2008). Species richness in the Foya Mountains is the poorest compared to those in various forests elsewhere (Fig. 13).

The species-area relationship is essential in ecology (Plotkin et al., 2000). It can be used to estimate species extinction due to habitat loss (May et al., 1995; Pimm \& Raven, 2000) and to appraise species diversity patterns in different forest types (Ashton, 1965). The curve is plotted to show species richness in relation to increasing size of the area (Mueller-Dombois \& Ellenberg, 1974) within the plot. In the present study, the minimal area could be identified as $5,000 \mathrm{~m}^{2}$. It was not, however, specifically intended to establish the minimal sampling area with the objective to obtain data using a single "minimal area" plot of the community (Mueller-Dombois \& Ellenberg, 1974). In general, this approach is difficult to apply in species-rich and complex tropical forests (Ashton, 1965; Mueller-Dombois \& Ellenberg, 1974), such as those of Sumatra and Kalimantan (Kartawinata et al., 2008), where there is no indication of levelling-off of the curve at the area of 10.5 ha. 
A dominant species utilizes a habitat efficiently and maximally compared to others (Smith, 1977). Species with high IV are more stable in terms of their persistence in growing and developing. In this context tree species with IV $>10 \%$ in the study plot will have better chances to grow and survive. They include Nothofagus rubra, Parinari corymbosa, Myristica hollrungii, Platea latifolia and Lophopetalum torricellense (Table 1).

A species is considered rare if, on the average, it has one or fewer stems per hectare (Hubbell \& Foster, 1986). Therefore, the nine species $(15.25 \%$ of the total) having a density of one/ha and frequency of $1 \%$ listed in Table 1 can be definitely considered rare. They were rare locally in the Foja Mountains but were not necessarily rare in terms of IUCN criteria. They were Antidesma sp., Cryptocarya caudata, Knema sp., Macaranga fallacina, Myristica fatua, Syzygium antisepticum, $S$. platycarpum, $S$. insulare and Polyosma integrifolia.

Structure and composition of the Foja Mountains forest consisted of different species living naturally as the results of adaptation to the biotic and abiotic environment (Hutchinson et al., 1999). Topographic differences may affect not only the number of species and density but also species grouping to form a floristic composition of the forest, as affirmed by Whitmore (1984) who stated that forest variations are related to terrain, topography and degree of natural disturbance. In the present study, differences in topography did not appear to affect the overall tree distribution as indicated by all the subplots being equally filled up by trees (Fig. 11). The existence of gaps allowed light to reach the forest floor that stimulates the germination of buried seeds of primary as well as secondary forest species (Hartshorn, 1980; Whitmore, 1984). Therefore, the species composition of a forest stand consists of both primary and secondary or successional species with their proportion depending on the degree of disturbance. Such mixture was evident at the Foja Mountains forest, although the proportion of the primary forest species was much greater than that of the secondary forest species because gaps are not too common. The secondary forest species filling up the gaps was small in number, which included Aporosa longicaudata, Croton laevifolius, Glochidion molle, G. novoguineense and Macaranga fallacina (Johns et al., 2007; Whitmore, 1984).

\section{CONCLUSION}

The account presented here is the first quantitative description ever made of the untouched superb and pristine lower montane forest in the isolated Foja Mountains in Papua, Indonesia. The one-hectare plot could be perceived as a representative sample of the surrounding forests as the minimal area was reached at 0.5 ha. Structurally and floristically the forest in the plot was an established and well developed mature undisturbed forest with heterogeneous species composition consisting mainly of primary forest species.

Heterogeneity was reflected by the majority of the species having low frequency $(<10 \%)$ and absolute density $(<10$ trees/ha), although species richness was low. The dominance of Nothofagus rubra signifies the status of this forest should be considered to be a variant of the lower montane and mid-montane forests of Papua dominated by Nothofagus pullei.

Allowing the pristine forest to remain undisturbed by human activities and permitting only natural disturbances and natural successions to take place will maintain the high value of the forest. It is one way to manage science-based conservation and management of the Foja Mountains. It should be supported by further research on the vegetation over a wider area in the reserve, including forests with low stature and bogs around the seasonally dry lake, as well as in the Mamberamo region.

Because of its uniqueness, the forest at the Foja Mountains should unquestionably at all costs be conserved with total protection to maintain the integrity and originality of the forests and prevent disturbances by human activities.

\section{ACKNOWLEDGEMENTS}

We would like to thank Prof. Jatna Supriatna, President of the Conservation International Indonesia (CII) for allowing one of us (AS) to participate in the CII expedition to the Foja Mountains undertaken in November 2005. We are very grateful to Mr. Tim Laman for allowing us to use his copyrighted photographs of the Foja Mountains to complement the article. Gratitude goes also to field staff of the Foja Wildlife Refuge: Mr. Bernat and Mr. Paulus who assisted us in the field. Appreciation also goes to Dr. Ary P. Keim (Botany). Dr. Hari Sutrisno, M. H. Sinaga and Suparno (Zoology) of the Research Center for Biology-LIPI, for their cooperation during the field work and to CII officers in Jakarta (Ms. Iraningrum) and Mr. Yance (Papua) for assistance and facilities that made participation in the expedition possible.

\section{REFERENCES}

ARCHBOLD, R., RAND, A. L. \& BRASS, L. J. 1942. Results of the Archbold expeditions. No. 41. Summary of the 1938-1939 New Guinea expedition. Bulletin of the American Museum 
of Natural History 73: 201-288.

ASHTON, P. S. 1965. Some problems arising in the sampling of mixed rain forest communities for floristic studies. In: Symposium on Ecological Research in Humid Tropics Vegetation (1963). 235-240. Government of Sarawak and UNESCO Science Cooperation Office for SE Asia. Tokyo Press Co. Ltd. Itabashi. Tokyo. $376 \mathrm{p}$.

BALGOOY, M. M. J. VAN. 1976. Phytogeography. In: PAIJMANS, K. (Ed.) New Guinea Vegetation. Australian National University Press. Canberra. Pp. 1-22.

BAPPENAS. 2003. Strategi dan Rencana Aksi Keanekaragaman Hayati Indonesia 2003-2020. IBSAP. Dokumen Nasional. Jakarta.

BARBOUR, M. G., BURK, J. H. \& PITTS, W. P. 1987. Terrestrial Plant Ecology. The Benjamin/Cumming Publishing Company Ins. California.

BEEHLER, B. M. 2007. The Foja Mountains of Indonesia: Exploring the lost world. Action bioscience, Pp.1-7.

BOERLAGE, H. P. 1949. Regenval in Indonesië (Rainfalll in Indonesia). Meteorologische en Geophysische Dienst. Koninklijk Magnetisch en Meteorologisch Observatorium te Batavia. Verhandelingen 37: 134.

BOWE, M., STRONACH, N. \& BARTOLO, R. 2007. Grassland and savanna ecosystems of the Trans-Fly, Southern Papua. In: MARSHALL, A. J. \& BEEHLER, B.M. (Eds.). The Ecology of Papua. Part II. Periplus Edition. Hongkong. Pp. 1054-1063.

BRASS, L. J. 1941. The 1938-1939 expedition to the Snow Mountains, Netherlands New Guinea. Journal of the Arnold Arboretum 22: 271-342.

CIESLA, W. M. \& DONAUBAUER, E. 1994. Decline and Dieback of Trees and Forests - A global review. FAO Forestry Paper 20. FAO. Rome.

CLIMATE-DATA.ORG 2017. Climate: Tembagapura. https://en.climate-data.org/ location/55120/https://id.climate-data.org/ location/600468. Accessed on 9 May 2017.

COLIJN, A. H. 1936. The Carstensz massif. Alpine Journal 49:177-189. https:// www.alpinejournal.org.uk/Contents/ Contents 1937_files/AJ49\%20177.189\% 20Colijn $\overline{\%} 20$ Cärstensz\%20Massif.pdf. Accessed on 28 Feb.2018.

COX, G. W. 1967. Laboratory Manual of General Ecology. Second Edition. Butterworths. Crown. Iowa.

GIBBS, L. S. 1917. A Contribution to the Phytogeography and Flora of the Arfak Mountains. Taylor \& Francis. London. http://papuaweb.org/ dlib/bk/gibbs/1917.html.

HARTSHON, G. S. 1980. Neotropical forest dynamic. Biotropica 12 (2): 23-30.
HEIST, M. VAN., SHEILL, D., RACHMAN, I., GUSBAGER, P., RAWEYAI, C. O. \& YOTENI, H. S. M. 2010. The forests and related vegetation of Kwerba on the Foja Foothills, Mamberamo, Papua (Indonesian New Guinea). Blumea 55: 153-161.

HOPE, G. S. 1976. Vegetation. In: HOPE, G. S., PETERSON, J. A., ALLISON, I. \& RADOCK, U. (Eds.). The Equatorial Glaciers of New Guinea. Balkema. Rotterdam. Pp. 113-172.

HUBBELL, S. \& FOSTER, R. 1986. Commonness and rarity in a neotropical forest: implications for tropical tree conservation. In: SOULE, M. (Ed.). Conservation Biology: The Science of Scarcity and Diversity. Sinauer Assoc. Inc. Sunderland. MA.

HUTCHINSON, T. F., BOERNER, R. E. J., IVERSON, L. R., SUTHERLAND, S. \& SUTHERLAND, E. K. 1999. Landscape patterns of understory composition and richness across a moisture and nitrogen mineralization gradient in Ohio (USA) Quercus forests. Plant Ecology 144: 177-189.

JOHNS, R. J. 1993. Biodiversity and conservation on the native flora of Papua New Guinea. In: ALCORN, J. B. (Ed.). Papua New Guinea Conservation Needs Assessment. Biodiversity Support Program. Washington. D.C. Pp. 15-75.

JOHNS, R. J., SHEA, G. A., VINK, W. \& PURADYATMIKA, P. 2007. Coastal vegetation of Papua; Lowland swamp and peat vegetation of Papua; Lowland vegetation of Papua; Heath vegetation of Papua; Mountain vegetation of Papua; Subalpine and alpine vegetation of $\mathrm{Pa}-$ pua. In: MARSHALL, A. J. \& BEEHLER, B. M. (Eds.). The Ecology of Papua. Part II. Periplus Edition. Hongkong. Pp. 901-908; 910 944; 945-961; 962-978; 977-1024; 1025-1053.

KALKMAN. C. 1963. Description of vegetation types in the Star Mountains region. West New Guinea. Nova Guinea Botany 15: 247-261.

KARTAWINATA. K. 2005. Six decades of natural vegetation studies in Indonesia. In: SOEMODIHARDJO, S. \& SASTRAPRADJA, S. D. (Eds.). Six Decades of Science and Scientists in Indonesia. Naturindo. Bogor. Pp. 95140.

KARTAWINATA. K. 2013. Diversitas Ekosistem Alami Indonesia (Ungkapan singkat dengan sajian foto dan gambar). LIPI Press \& Yayasan Pustaka Obor Indonesia. Jakarta.

KARTAWINATA, K., SAMSOEDIN, I., HERIYANTO, M. \& AFRIASTINI, J. J. 2004. A tree species inventory in a one-hectare plot at the Batang Gadis National Park. North Sumatra. Indonesia. Reinwardtia 12 (2): 145-157.

KARTAWINATA, K., PURWANINGSIH, PARTOMIHARDJO, T., YUSUF, R., ABDULHADI, R. \& RISWAN, S. 2008. Floristics and structure of a lowland dipterocarp forest at 
Wanariset Samboja. East Kalimantan. Indonesia. Reinwardtia 12 (4): 301-323.

KARTIKASARI, S. N., MARSHALL, A. J. \& BEEHLER, B. M. 2012. Ekologi Papua. Yayasan Pustaka Obor Indonesia \& Conservation International. Jakarta.

KEIM, A. P., KARTAWINATA, K., \& EFFENDY, O. 2018. Biodiversitas terkini Danau Habbema, Papua. Unpublished.

KERSHAW, K. A. 1964. Quantitative and Dynamic Ecology. Edward Arnold Publishing Co. Ltd. London.

KLHK (Kementerian Lingkungan Hidup dan Kehutanan). 2016. Statistik Kehutanan Tahun 2016. Kementerian Lingkungan Hidup dan Kehutanan. Jakarta.

LAM, H. J. 1945. Fragmenta Papuana 1-7. Translated by L. M. Perry. Sargentea 5: 1-196. http://awsassets.panda.org/downloads/ prentice_hope_climate_papua_2006.pdf

LAMAN, T. 2009. Explore Foja Mountains, Mountains Papua and more! https:// www.pinterest.com/pin. Accessed 30 January 2017.

LANE-POOLE, C. E. 1925. The Forest Resources of the Territories of Papua and New Guinea. Govt. Printer. Melbourne.

LIPI (Lembaga Ilmu Pengetahuan Indonesia), KPPN (Kementerian Perencanaan Pembangunan Nasional) \& KRT (Kementrian Riset dan Teknologi). 2013. Bioresources Pembangunan Ekonomi Hijau. LIPI Press. Jakarta.

McCUNE, B. \& GRACE, J. B. 2002. Analysis of Ecological Communities. MJM Software Design. Gleneden Beach. Oregon.

MAMPIOPER, D. A. 2009. Suaka Margasatwa Mamberamo Foja. Rawan Perburuan Liar dan Pembangunan. http://tabloidjubi.com. Accessed 17 January 2017.

MANGEN, J. M. 1993. Ecology and vegetation of Mt. Trikora, New Guinea (Irian Jaya/Indonesia). Travaux Scientifiques du Musée National d'Histoire Naturelle de Luxembourg 21:1-216.

MANSUR, M. \& KARTAWINATA, K. 2017. Phytosociology of a lower montane forest on Mt. Batulanteh, Sumbawa, Indonesia. Reinwardtia 16 (2): 77-92.

MAY, R. J., LAWTON, J. \& STORK, N. 1995. Extinction rates. In: LAWTON, J. \& MAY, R. (Eds.). Oxford. University Press. Oxford. Pp: 124.

MOGEA, J. P. 2005. Palm in the Foja Mountain, Upper Mamberamo River, Sarmi District, Papua, Indonesia. Rapid A ssessment Program. (Field-trip Report).

MUELLER-DOMBOIS, D. 1983. Canopy dieback and successional process in Pacific forests. Pacific Science 37: 317-325.

MUELLER-DOMBOIS, D. 1986. Perspective for etiology of stand level dieback. Annual Review of Ecology and Systematics 17: 221-241.

MUELLER-DUMBOIS, D. \& ELLENBERG, H. 1974. Aim and Methods of Vegetation Ecology. John Willey Toronto.

PAIJMANS, K. 1970. An analysis of four tropical rain forest sites in New Guinea. Journal of Ecology 58: 77-101.

PAIJMANS, K. 1976. New Guinea Vegetation. Australian National University Press. Canberra.

PARTOMIHARDJO, T. 1991. Analisis vegetasi hutan sekitar Air Garam, Jayawijaya. In: WITJAKSONO, MARWOTO, R. M. \& SUPARDIYONO, E. K. (Eds.). Prosiding Seminar Hasil Penelitian dan Pengembangan Sumber Daya Hayati 1990/1991. Puslitbang BiologiLIPI, Bogor. Pp. 15-23.

PIMM, S. \& RAVEN, P. 2000. Extinction by numbers. Nature 403: 843-845.

PLOTKIN, J. B., POTTS, M. D., LESLIE, A. N., MANOKARAN, N., LAFRANKIE, J. \& ASHTON, P. S. 2000. Species-area curves, spatial aggregation, and habitat specialization in tropical forests. J. Theor. Biol. 207: 81-99.

POLAK, M. 2000. The botanical diversity in the Ayawasi area, Irian Jaya, Indonesia. Biodiversity and Conservation 9: 1345-1375.

PURWANINGSIH \& YUSUF, R. 2008. Analisis vegetasi hutan pegunungan di Taman Nasional Gunung Ceremai, Majalengka, Jawa Barat. Jurnal Biologi Indonesia 4(5): 385-399.

PURWANINGSIH, POLOSAKAN, R. \& YUSUF, R. 2017. Phytosociological studies of the montane forest on the south slope of Mt. Wilis, East Java, Indonesia. Reinwardtia 16 (1): 31-45.

RAHMAH, KARTAWINATA, K., NISYAWATI, WARDHANA, W. \& NURDIN, E. 2016. Tree species diversity in the lowland forest of the core zone of the Bukit Duabelas National Park, Jambi, Indonesia. Reinwardtia 15 (1): 11-26.

RICHARDS, P. W. 1996. The Tropical Rain Forest: An Ecological Study. 2nd edition. Cambridge University Press. Cambridge. UK.

ROBERTH, 2016. Mamberamo Foja Diusul Jadi Taman Nasional. http://www.wartaplus.com. Accessed on 17 January 2017.

SAMBAS, E. N. 2014. Komposisi jenis pohon pada hutan pamah Mamberamo, Papua. In: MEGANTARA, E.N., SUPRIATUN T., ROSSIANA, N., HUSODO, T., MIRANTI, M., WULANDARI, A. P., DEWI, T. K. P., SYARIF, S., SANTOSA, P. \& ANNISA (Eds). Prosiding Seminar Nasional IV Jurusan Biologi -FMIPA, Universitas Padjadjaran. Pp. 234 244.

SCHMIDT, F. H. \& FERGUSON, J. H. 1951. Rainfall Types Based on Wet and Dry Period Rations for Indonesia with Western New Guinea. Verhandelingen Djawatan Meteorologi dan Geofisika. Djakarta. 
SHEA, G. A., MARTINDALE, D., PURADYATMIKA, P. \& MANDESSY, A. 1998. Biodiversity Surveys in the PT Freeport Indonesia Contract of Work Mining and Project Area, Irian Jaya, Indonesia. P.T. Freeport. Indonesia.

SIREGAR, M. 2001. Pengaruh topografi terhadap vegetasi hutan pada formasi Wainukendi, Cagar Alam Supiori, Irian Jaya. Ekologi Indonesia 3 (1): 22-33.

SMITH, R. L. 1977. Element of Ecology. New York: Harper \& Row Publisher.

SOEPADMO, E. 1972. Fagaceae. Flora Malesiana I. 7: 265-403.

STEENIS, C. G. G. J. VAN. 1950. The delimitation of Malaysia and its main plant geographic divisions. In: STEENIS, C. G. G. J. VAN (General Editor) Flora Malesiana Ser. I. Volume I. Noordhoff-Kolff. N.V. Djakarta. Pp. lxxi-lxxv.

STEENIS, C. G. G. J. VAN, KALKMAN, C., KIRKUP, D. W., NOTEBOOM, H. P., WILDE, W. J. J. O. DE., SAW, L. G., STEVENS, P. F., COODE, M. J. E. \& WELZEN, P. C. VAN (Eds.). 1948-2013. Flora Malaesiana. Series I. Volumes 4-21. Foundation Flora Malesiana. Leiden.

TAKEUCHI, W. 2007. Introduction to the flora of Papua. In: MARSHALL, A. J. \& BEEHLER, M. B. (Eds.). The Ecology of Papua. The Ecology of Indonesia Series. Vol. 6. Periplus Editions (HK) Ltd. Hong Kong. Pp. 269-302.

TAKEUCHI, W. 2009. New taxa from the Mamberamo River of Papua Province, Indonesia: Ardisia lammersiana (Myrsinaceae) and Psychotria leptothyrsa var. defretesiana (Rubiaceae). Harvard Papers in Botany 14(2):
173-181.

TAKEUCHI, W. 2010. A floristic reconnaissance of montane environments in the Foja Mts. of Papua Province, Indonesia. Harvard Papers in Botany 15(1): 11-25.

TAKEUCHI, W. \& ARIFIANI, D. 2010. A synopsis of new plant distributional records from the Foja Mountains of Papua Province, Indonesia. Harvard Papers in Botany 15(1): 4150.

THE PLANT LIST. 2017. The Plant List: A working list of all known plant species Version 1.1 (September 2013). http://www.theplantlist.org. Accessed on 30 February 2017.

YAMADA, I. 1975. Forest ecological studies of the montane forest of Mt. Pangrango. West Java. I. Stratification and floristic composition of the montane rain forest near Cibodas. South East Asia Studies 13 (3): 402-426.

WALTER, H. 1973. Vegetation of the Earth. (English edition). The English Universities Press. London.

WHITMORE, T. C. \& SIDIYASA, K. 1986. Composition and structure of a lowland rain forest at Toraut, northern Sulawesi. Kew Bulletin 41: 747-756.

WHITMORE, T. C., TANTRA, I. G. M. \& SUTISNA, U. 1997. Tree Flora of Indonesia. Check List for Irian Jaya. Forest Research and Development Centre. Bogor.

WHITMORE, T. C. 1984. Tropical Rain Forest of the Far East. $\left(2^{\text {ed }}\right)$. Clarendon University Press. Oxford.

ZUHRI, M \& MUTAQIN, Z. 2011. Perubahan komposisisi vegetasi dan struktur pohon pada plot Meijer (1959-2009) di Gunung Gede, Jawa Barat. Buletin Kebun Raya 14 (1): 37-45. 


\section{INSTRUCTION TO AUTHORS}

Scope. Reinwardtia is a scientific regular journal on plant taxonomy, plant ecology and ethnobotany published in June and December. Manuscript intended for a publication should be written in English.

Titles. Titles should be brief, informative and followed by author's name and mailing address in oneparagraphed.

Abstract. English abstract followed by Indonesian abstract of not more than 250 words. Keywords should be given below each abstract.

Manuscript. Manuscript is or iginal paper and represent an article which has not been published in any other journal or proceedings. The manuscript of no more than 36 pages by using Times New Roman 11, MS Word for Windows of A4 with double spacing, submitted to the editor through Reinwardtia online journal system and < reinwardtia@mail.lipi.go.id>. New paragraph should be indented in by 5 characters. For the style of presentation, authors should follow the latest issue of Reinwardtia very closely. Author(s) should send the preferred running title of the article submitted. Every manuscript will be sent to two blind reviewers.

Identification key. Taxonomic identification key should be prepared using the aligned couplet type.

Nomenclature. Strict adherence to the International Code of Nomenclature is observed, so that taxonomic and nomenclatural novelties should be clearly shown. English description for new taxon proposed should be provided and the herbaria where the type specimens area deposited should be presented. Name of taxon in taxonomic treatment should be presented in the long form that is name of taxon, author's name, year of publication, abbreviated journal or book title, volume, number and page.

Map/line drawing illustration/photograph. Map, line drawing illustration, or photograph preferably should be prepared in landscape presentation to occupy two columns. Illustration must be submitted as original art accompanying, but separated from the manuscript. The illustration should be saved in JPG or GIF format at least 350 pixels. Legends or illustration must be submitted separately at the end of the manuscript.

References. Bibliography, list of literature cited or references follow the Harvard system as the following examples.

Journal : KRAENZLIN, F. 1913. Cyrtandraceae novae Philippinenses I. Philipp. J. Sci. 8: 163-179.

MAYER, V., MOLLER, M., PERRET, M. \& WEBER, A. 2003. Phylogenetic position and generic differentiation of Epithemateae (Gesneriaceae) inferred from plastid DNA sequence data. American J. Bot. 90: 321-329.

Proceedings : TEMU, S. T. 1995. Peranan tumbuhan dan ternak dalam upacara adat "Djoka Dju" pada suku Lio, Ende, Flores, Nusa Tenggara Timur. In: NASUTION, E. (Ed.). Prosiding Seminar dan Lokakarya Nasional Etnobotani II. LIPI \& Perpustakaan Nasional: 263-268. (In Indonesian).

SIMBOLON, H. \& MIRMANTO, E. 2000. Checklist of plant species in the peat swamp forests of Central Kalimantan, Indonesia. In: IWAKUMA, T., INOUE, T., KOHYAMA, T., OSAKI, M., SIMBOLON, H., TACHIBANA, H., TAKAHASHI, H., TANAKA, N., YABE, K. (Eds.). Proceedings of the International Symposium on: Tropical Peatlands. Pp.179 - 190.

Book : RIDLEY, H. N. 1923. Flora of the Malay Peninsula 2. L. Reeve \& Co. Ltd, London.

Part of Book : BENTHAM, G. 1876. Gesneriaceae. In: BENTHAM, G. \& HOOKER, J. D. Genera Plantarum 2. Lovell Reeve \& Co., London. Pp. 990-1025.

Thesis : BAIRD, L. 2002. A Grammar of Kéo: An Austronesian Language of East Nusantara. Australian National University, Canberra. [PhD. Thesis].

Website : http://www.nationaalherbarium.nl/fmcollectors/k/KostermansAJGH.html. (Accessed 15 February 2012). 


\section{Reinwardtia}

Published by Herbarium Bogoriense, Botany Division, Research Center for Biology, Indonesian Institute of Sciences

Address: Jln. Raya Jakarta-Bogor Km. 46 Cibinong 16911, P.O. Box 25 Cibinong

Telp. (+62) 21 8765066; Fax (+62) 218765062

LIPI

Email: reinwardtia@mail.lipi.go.id

\section{REINWARDTIA Author Agreement Form}

Title of article

Name of Author(s) :

I/We hereby declare that:

- $\mathrm{My} / \mathrm{Our}$ manuscript was based on my/our original work.

- It was not published or submitted to other journal for publication.

- I/we agree to publish my/our manuscript and the copyright of this article is owned by Reinwardtia.

- We have obtained written permission from copyright owners for any excerpts from copyrighted works that are included and have credited the sources in our article. 



\section{REINWARDTIA}

Vol. 17. No. 2. 2018

CONTENTS

LAODE ALHAMD. Ecological study of the arrowroot (Tacca leontopetaloides (L.) Kuntze) at Karimunjawa National Park (KNP), Central Java

YASPER MICHAEL MAMBRASAR \& PRIMA W. K. HUTABARAT. Rhododendron meagaii, a new species of Rhododendron subgenus Vireya (Ericaceae) from Papua, Indonesia

K. M. WONG, RIDHA MAHYUNI, XIN YI NG \& LOUISE NEO. Flora of Singapore Precursors, 8. Systematy of the new Southeast Asian genera Canthiumera and Dibridsonia (Rubiaceae: Vanguerieae), with notes on plant architecture and reproductive ecology

ANDREW POWLING. An assessment of present plant diversity on the Natewa Peninsula, Vanua Levu, Fiji 125

ASEP SADILI, KUSWATA KARTAWINATA, HERWASONO SOEDJITO \& EDY NASRIADI SAMBAS. Tree species diversity in a pristine montane forest previously untouched by human activities in Foja Mountains, Papua, Indonesia

Reinwardtia is a LIPI accredited Journal (792/AU3/P2MI-LIPI/04/2016)

http://e-journal.biologi.lipi.go.id/index.php/reinwardtia

Herbarium Bogoriense

Botany Division

Research Center for Biology - Indonesian Institute of Sciences

Cibinong Science Center

Jln. Raya Jakarta - Bogor, Km 46

Cibinong 16911, P.O. Box 25 Cibinong

Indonesia 